\title{
Global change and the future of harmful algal blooms in the ocean
}

\author{
Fei Xue Fu*, Avery O. Tatters, David A. Hutchins \\ The University of Southern California, Department of Biological Sciences, 3616 Trousdale Parkway, Los Angeles, \\ California 90089, USA
}

\begin{abstract}
The frequency and intensity of harmful algal blooms (HABs) and phytoplankton community shifts toward toxic species have increased worldwide. Although most research has focused on eutrophication as the cause of this trend, many other global- and regional-scale anthropogenic influences may also play a role. Ocean acidification (high $\mathrm{pCO}_{2} / \mathrm{low} \mathrm{pH}$ ), greenhouse warming, shifts in nutrient availability, ratios, and speciation, changing exposure to solar irradiance, and altered salinity all have the potential to profoundly affect the growth and toxicity of these phytoplankton. Except for ocean acidification, the effects of these individual factors on harmful algae have been studied extensively. In this review, we summarize our understanding of the influence of each of these single factors on the physiological properties of important marine HAB groups. We then examine the much more limited literature on how rising $\mathrm{CO}_{2}$ together with these other concurrent environmental changes may affect these organisms, including what is possibly the most critical property of many species: toxin production. New work with several diatom and dinoflagellate species suggests that ocean acidification combined with nutrient limitation or temperature changes may dramatically increase the toxicity of some harmful groups. This observation underscores the need for more in-depth consideration of poorly understood interactions between multiple global change variables on HAB physiology and ecology. A key limitation of global change experiments is that they typically span only a few algal generations, making it difficult to predict whether they reflect likely future decadal- or century-scale trends. We conclude by calling for thoughtfully designed experiments and observations that include adequate consideration of complex multivariate interactive effects on the long-term responses of HABs to a rapidly changing future marine environment.
\end{abstract}

KEY WORDS: Climate change $\cdot \mathrm{CO}_{2} \cdot$ Ocean acidification $\cdot$ Temperature $\cdot$ Stratification $\cdot$ Nutrient limitation $\cdot \mathrm{HAB} \cdot$ Algal toxins $\cdot$ Phycotoxins

Resale or republication not permitted without written consent of the publisher

\section{INTRODUCTION}

Anthropogenic eutrophication has been linked to worldwide increases in harmful algal bloom (HAB) frequency and intensity in recent decades (Honjo 1993, Anderson et al. 2002, Glibert et al. 2005, Hallegraeff 2010). In response to these observations, a great deal of research has focused on the influence of changing nutrient availability on algal bloom establishment and growth. Eutrophication, however, is only one of multiple global anthropogenic biogeochemical impacts.
In addition to disturbance of natural nutrient cycles, humans are also causing a massive perturbation of the global carbon cycle. The atmospheric partial pressure of $\mathrm{CO}_{2}\left(\mathrm{pCO}_{2}\right)$ has risen by $>30 \%$ due to the burning of fossil fuels, deforestation, industrialization, and cement production (IPCC 2007). These already elevated current $\mathrm{CO}_{2}$ levels will approximately double from $\sim 385$ to $750-800$ ppm by 2100 , and ocean $\mathrm{pH}$ will consequently decrease by as much as 0.77 units over the next several hundred years (Caldeira \& Wickett 2003), with unknown consequences for many $\mathrm{pH}$-sensitive marine organisms 
(Royal Society 2005, Orr et al. 2005, Hoegh-Guldberg \& Bruno 2010). We know that ocean acidification can have potentially far-reaching consequences for the physiology of many algal groups, including altered growth and carbon fixation rates, shifts in nutrient uptake, changes in elemental ratios, and increased sensitivity to ultraviolet radiation (Riebesell 2004, Fu et al. 2007, 2008a,b, 2010, Feng et al. 2008, 2009, 2010, Hutchins et al. 2007, 2009, Riebesell et al. 2007, 2008, Rost et al. 2008, Beardall et al. 2009a, Gao et al. 2012a, this Theme Section). These physiological responses may be reflected at the ecosystem level through changes in algal competitive interactions, ecological dominance, and overall community structure (Tortell et al. 2002, Riebesell 2004, Hare et al. 2007, Feng et al. 2009, 2010).

Primary producers including HAB species must adjust not only to altered seawater carbonate chemistry, but also to numerous other concurrent environmental changes. Over the next 50 to $100 \mathrm{yr}$, greenhouse warming will increase average sea surface temperatures by as much as $5^{\circ} \mathrm{C}$, and increased precipitation, runoff, and ice melting will lower surface salinities in many parts of the ocean (Bopp et al. 2001, Sarmiento et al. 2002). The combined influence of warming and freshening on the density of seawater will cause much of the surface ocean to become more stratified, driving fundamental shifts in key biological variables such as nutrient supplies and light exposure regimes (Boyd \& Doney 2003, Boyd et al. 2008, 2010, Cermeño et al. 2008, Hutchins et al. 2009). As a consequence of these environmental changes, marine ecosystems all over the world are currently changing at an alarming rate. Long-term data sets from around the world suggest that ongoing changes in coastal and estuarine phytoplankton communities are likely due to the combination of climate shifts and other anthropogenic influences (Edwards et al. 2006, Smetacek \& Cloern 2008).

Only a few studies to date have directly addressed the implications of ocean global change for HAB species, and most of these have considered the effects of warming (Peperzak 2003, 2005, Cloern et al. 2005, Moore et al. 2008, 2009, Paerl \& Huisman 2008). However, it is virtually certain that harmful blooms of the future will also be simultaneously affected by interactions with the complex network of other changing environmental variables discussed above. Recent evidence demonstrates that some coastal ecosystems and estuaries are already experiencing significant levels of anthropogenic acidification (Feely et al. 2008, Cai et al. 2011). Since HABs often occur in these types of ecosystems, there is an urgent need to investigate how they will respond to changing $\mathrm{CO}_{2}$ and/or $\mathrm{pH}$ both alone and in combination with other variables. Accurately predicting the responses of HABs to these many interacting anthropogenic changes is a top priority for everyone who must deal with the negative impacts of toxic algal blooms, including marine resource managers, policy makers, governmental management agencies, and marine resource users such as the seafood harvesting and aquaculture industries. The goal of this review is to summarize the effects of rising $\mathrm{pCO}_{2}$ in concert with other global change factors on the physiological and ecological responses these organisms.

Our review is intended to expand on the excellent recent review of HABs and global change by Hallegraeff (2010), by focusing on how we may apply the results of a large body of prior work on environmental perturbation effects on HABs to understand their responses to a rapidly changing ocean. Equally importantly, we also emphasize the results of new experiments specifically targeting global change effects on HABs in this rapidly expanding field. First, we briefly review the relevant literature on the effects of individual global change-relevant variables on growth and toxicity, including nutrients, temperature, solar radiation, and salinity. In the final sections of our review, we cover the limited but particularly important body of HAB-related research examining multivariate interactions between these environmental factors and $\mathrm{CO}_{2}$-driven ocean acidification.

\section{EFFECTS OF INDIVIDUAL GLOBAL CHANGE FACTORS ON HARMFUL ALGAE

$$
\mathrm{pCO}_{2} / \mathrm{pH}
$$

Despite the extensive recent research effort that has been directed toward understanding ocean acidification effects on diverse marine organisms, only a handful of studies have so far addressed how $\mathrm{CO}_{2}$ or $\mathrm{pH}$ changes affect HAB physiology and toxicity. Some bloom-forming dinoflagellates may especially benefit from higher $\mathrm{pCO}_{2}$, due in part to their $\mathrm{CO}_{2}$ fixing enzyme, a type II Rubisco (ribulose-1,5-bisphosphate carboxylase-oxygenase; Tortell 2000, Rost et al. 2003). Type II Rubisco has a low affinity for carboxylation and is therefore extremely inefficient at processing $\mathrm{CO}_{2}$ at present-day atmospheric concentrations, compared to the type I Rubisco found in most other algae. Dinoflagellates overcome this limitation, in part, by compartmentalizing Rubisco within the chloroplast to avoid photorespiration (Jenks \& 
Gibbs 2000, Nassoury et al. 2001). This low-affinity $\mathrm{CO}_{2}$-fixing system may also be compensated for by efficient carbon-concentrating mechanisms (CCMs) such as various forms of carbonic anhydrase (CA), which allow algae to access the much more abundant pool of $\mathrm{HCO}_{3}{ }^{-}$in seawater. These adaptations allow some dinoflagellates to grow rapidly at present day $\mathrm{pCO}_{2}$ levels, and it is unknown for most species whether elevated $\mathrm{CO}_{2}$ will enhance growth further by offsetting the physiological constraints of their type II Rubisco.

Dason et al. (2004) showed that the marine dinoflagellates Amphidinium carterae and Heterocapsa oceanica do not possess an external $\mathrm{CA}$, and thus their photosynthesis is dependent on free $\mathrm{CO}_{2}$ alone. Consequently, the growth of these 2 species is suggested to be $\mathrm{CO}_{2}$-limited (Colman et al. 2002, Dason et al. 2004), and their growth could potentially be stimulated by increasing $\mathrm{CO}_{2}$ concentrations in the future ocean. In contrast, the growth rates of 3 other marine dinoflagellates (Prorocentrum minimum, $H$. triquetra, and Ceratium lineatum) are most likely not limited by dissolved inorganic carbon, since they preferentially take up $\mathrm{HCO}_{3}{ }^{-}$instead of $\mathrm{CO}_{2}$ to support photosynthesis (Rost et al. 2006). This observation is supported by the finding that increasing $\mathrm{CO}_{2}$ does not significantly affect the growth rate of another isolate of P. minimum (Fu et al. 2008a).

Because phycotoxin biosynthesis is directly linked to the autotrophic metabolism of most HAB species, it is perhaps not entirely surprising to find that changing $\mathrm{CO}_{2}$ availability can also affect cellular toxicity. Photosynthesis is not only the essential process in primary metabolism, but is also required for toxin production (Pan et al. 1996a). For example, the yield of saxitoxin per cell in the dinoflagellate Alexandrium catenella is proportional to hours of daylight (Proctor et al. 1975). Also, A. minutum is not capable of producing saxitoxin after a $22 \mathrm{~d}$ incubation period in the dark, while parallel light-grown cultures produced $1.17 \mu \mathrm{g}$ per 10000 algal cells (Maas \& Brooks 2010).

$\mathrm{pCO}_{2}$ and/or $\mathrm{pH}$ changes affect toxicity of the diatom genus Pseudo-nitzschia, which causes notoriously damaging blooms along the Pacific coast of North America and elsewhere around the world (Scholin et al. 2000, Trainer et al. 2000, 2009, Schnetzer et al. 2007). Two recent studies have examined the influence of seawater $\mathrm{pH}$ on the toxicity of cultures of Pseudo-nitzschia spp.: Sun et al. (2011) and Tatters et al. (2012) found that domoic acid concentrations increase dramatically in treatments combining high $\mathrm{pCO}_{2}$ /low $\mathrm{pH}$ (adjusted by bubbling the seawater with $\mathrm{CO}_{2}$-enriched air) with nutrient limitation. The authors speculated that $\mathrm{pCO}_{2-}$ induced domoic acid production is perhaps a consequence of an excess in carbon supply when elevated $\mathrm{CO}_{2}$ occurs together with nutrient-limited growth conditions. Interestingly though, 2 previous studies found results that differ from these 2 recent studies, in that domoic acid levels increased instead at higher pHs (e.g. lower $\mathrm{pCO}_{2}$; Lundholm et al. 2004, Trimborn et al. 2008). It is worth noting that unlike the 2 more recent studies, in these earlier experiments $\mathrm{pH}$ was adjusted by $\mathrm{HCl}$ and $\mathrm{NaOH}$ addition rather than by $\mathrm{CO}_{2}$ bubbling. The 2 recent multivariate studies, and possible reasons for these apparently contradictory results, are considered further in the 'Interactive effects of $\mathrm{CO}_{2}$ and nutrients' section below. Despite the differences in their findings, all 4 of these studies support the suggestion that $\mathrm{pCO}_{2} / \mathrm{pH}$ can strongly influence the production of domoic acid by this globally distributed diatom genus.

The impact of elevated $\mathrm{CO}_{2}$ on the growth of $\mathrm{CCM}$ utilizing diatoms versus algal species without a CCM (Riebesell 2004) suggests that those species which lack CA will likely benefit most from rising $\mathrm{CO}_{2}$ levels. Notably, the raphidophyte Heterosigma akashiwo does not appear to use CA (Nimer et al. 1997), suggesting that it may be especially favored by rising $\mathrm{CO}_{2}$ levels. In fact, the growth of $H$. akashiwo is significantly stimulated by increasing $\mathrm{CO}_{2}$, again achieved by bubbling the seawater with air $/ \mathrm{CO}_{2}$ mixtures (Fu et al. 2008a). However, this finding may not apply to all raphidophytes. For instance, the growth of Chattonella marina is not affected by $\mathrm{pH}$ over a range from 7.5 to 8.5 (adjusted by acid and base additions), although growth greatly decreases at $\mathrm{pH}$ values over 9.0 (Liu et al. 2007). Coupled with these reduced growth rates, rates of ichthyotoxic reactive oxygen species (ROS) production by $C$. marina also increase at this elevated $\mathrm{pH}$, but remain stable within the $\mathrm{pH}$ range of 7.5 to 8.5 . Liu et al. (2007) suggested that high $\mathrm{pH}$ may enhance the activities of enzymes that regulate ROS production, and/or that high $\mathrm{pH}$ may reduce iron bioavailability to the algae.

The prymnesiophyte Phaeocystis globosa can form massive harmful blooms in temperate areas such as the North Sea. Recent evidence suggests that its physiological responses to changing $\mathrm{pCO}_{2}$ may be dependent on its polymorphic life history, which alternates between solitary flagellated cells and colonies composed of numerous cells embedded in a gelatinous matrix. Wang et al. (2010) demonstrated that bubbling P. globosa cultures with elevated $\mathrm{CO}_{2}$ 
stimulates the formation and growth rates of colonies, but the growth rates of solitary cells are unchanged. Based on the observed increases in colony formation, these authors suggest that future rising $\mathrm{CO}_{2}$ may affect carbon and sulfur cycles as well as marine trophic structure both locally and regionally. However, a natural assemblage of the closely related polar species $P$. antarctica is relatively unaffected by extended incubation at elevated $\mathrm{pCO}_{2}$ (Feng et al. 2010).

This short list summarizes the published studies on $\mathrm{HAB}$ species responses to ocean acidification in isolation; these experiments and a few others examining rising $\mathrm{pCO}_{2}$ in combination with other variables are summarized in Table 1 and are reviewed below. This surprising paucity of information on high $\mathrm{pCO}_{2}$ /low $\mathrm{pH}$ effects needs to be remedied by further studies using a variety of environmentally relevant species, thus there is likely to be new information available on this subject within the next few years.

\section{Temperature}

Temperature is probably the most widely recognized component of climate change and also plays a crucial role in determining potential algal growth rates. Consequently, temperature can influence community dynamics of harmful bloom species relative to their competitors and grazers. In diatoms, for example, nitrate uptake and reduction decline rapidly at elevated temperatures (Lomas \& Glibert 1999), potentially favoring competing algae. Likewise, temperature can differentially impact the growth rate, pigment content, light-harvesting capacity, and photosynthetic carbon fixation of many microalgae (Sosik \& Mitchell 1994, Coles \& Jones 2000, Anning et al. 2001, Stramski et al. 2002).

Increasing sea surface temperatures are already leading to prolonged and more intense temperatures during bloom seasons (Peperzak 2003, 2005, Edwards et al. 2006, Hallegraeff 2010, Paerl \& Scott 2010), and this trend is likely to continue with the potential for establishment of temporally and spatially expanded bloom windows (Fig. 1; Moore et al. 2008). Many HABs have a window of temperature that is reached and often exceeded within a given year (Gobler et al. 2005, Moore et al. 2008). Therefore, in some cases increasing temperature may not intensify HABs throughout the growing season, but perhaps instead change the timing of their initiation and termination during the annual seasonal cycle. Warm water temperatures, calm conditions, and accompa- nying stratification seem to promote the proliferation of many microalgae, including several harmful species (Paerl \& Scott 2010). Cellular toxicity can also be sensitive to rising temperature. For instance, cultures and field samples of Karlodinium veneficum exhibit increased cellular toxicity at temperatures $>25^{\circ} \mathrm{C}$ (Kempton et al. 2002, Adolf et al. 2009).

The relationship between HABs and warming is not always straightforward. As toxic diatoms of the genus Pseudo-nitzschia typically respond to seasonal patterns, temperature is likely a critical driver in their bloom development. Depending on geographical region, seasonal blooms have been correlated with pulses of cool, nutrient-rich upwelled water (Horner et. al 1997, Trainer et al. 2002, Kudela et al. 2010), and also with warmer, stratified conditions (Bird \& Wright 1989, Buck et al. 1992, Horner et al. 1997, Scholin et al. 2000). In the laboratory, growth rates of a temperate isolate of P. pseudodelicatissima increase up to $25^{\circ} \mathrm{C}$ (Lundholm et al. 1997). Temperature could also play a role in regulation of enzymatic pathways involved in domoic acid biosynthesis by Pseudo-nitzschia. Although there have been laboratory studies of Pseudo-nitzschia spp. growth rates as a function of temperature (Lundholm et al. 1997, Thessen et al. 2009), effects on domoic acid production have been examined surprisingly seldom. In 2 culture studies, warmer temperatures were not demonstrated to accelerate domoic acid production (Lundholm et al. 1994, Bates et al. 1998). Similarly, little or no correlation was observed between cellular domoic acid and temperature during field observations in Chesapeake Bay and the northern Gulf of Mexico (Thessen \& Stoecker 2008, MacIntyre et al. 2011).

Temperature shifts may affect the spread of Pseudo-nitzschia to new habitats. The persistent seasonal nature of these blooms once seed populations become established in supportive areas can be quite remarkable. For instance, recent data from Barron et al. (2010) suggest that cooling waters of the North Pacific influenced by the negative Pacific Decadal Oscillation have coincided with the sudden 1999 appearance of $P$. australis and $P$. multiseries in the sedimentary record of California's Santa Barbara basin. These HAB diatoms remained significantly more abundant relative to other diatoms such as Chaetoceros and Rhizosolenia spp. as of 2003. Although blooms of toxic Pseudo-nitzschia spp. are now a common annual feature of this region, this study could also be taken to suggest that long-term warming trends might contract the ranges of these organisms. 


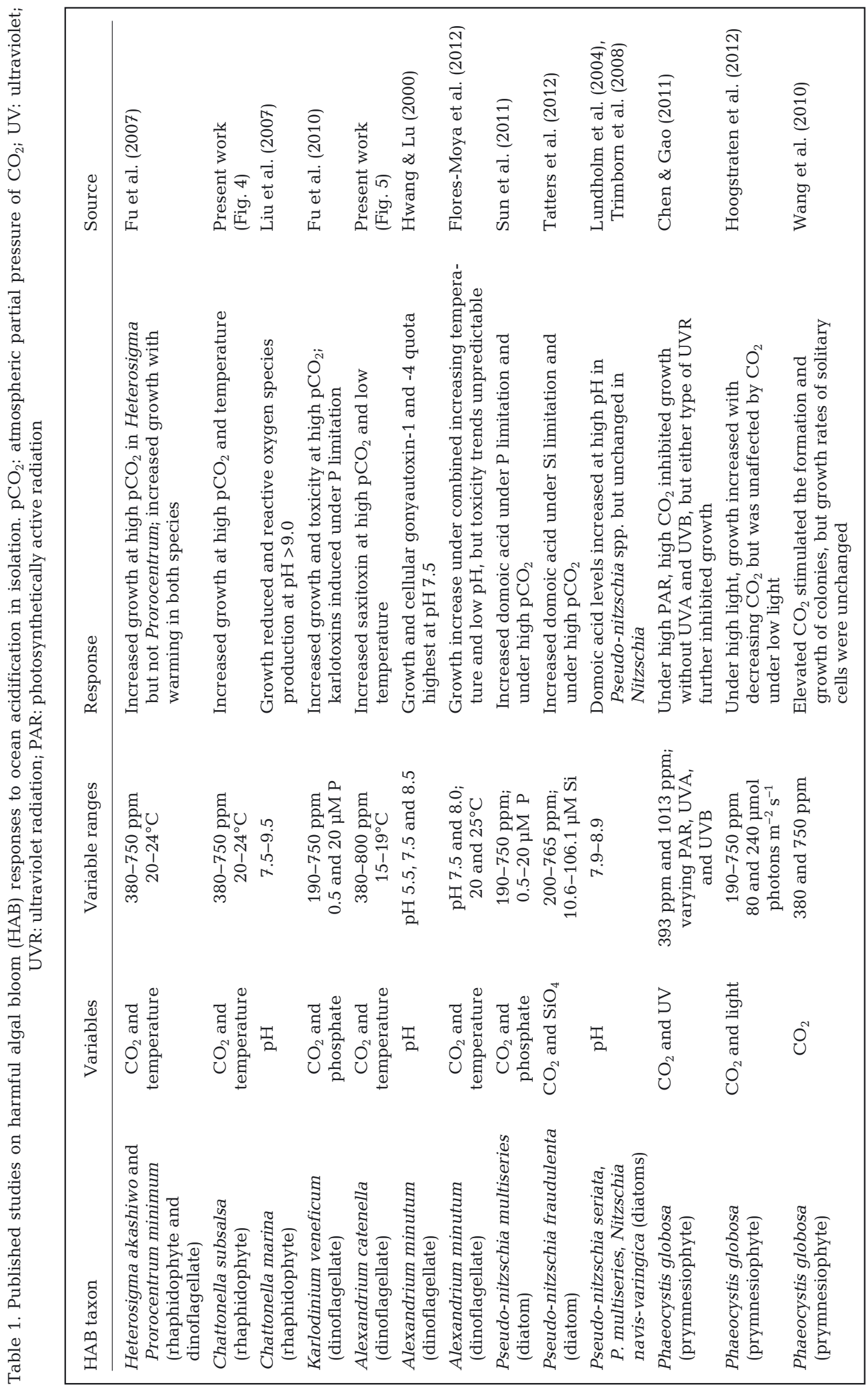




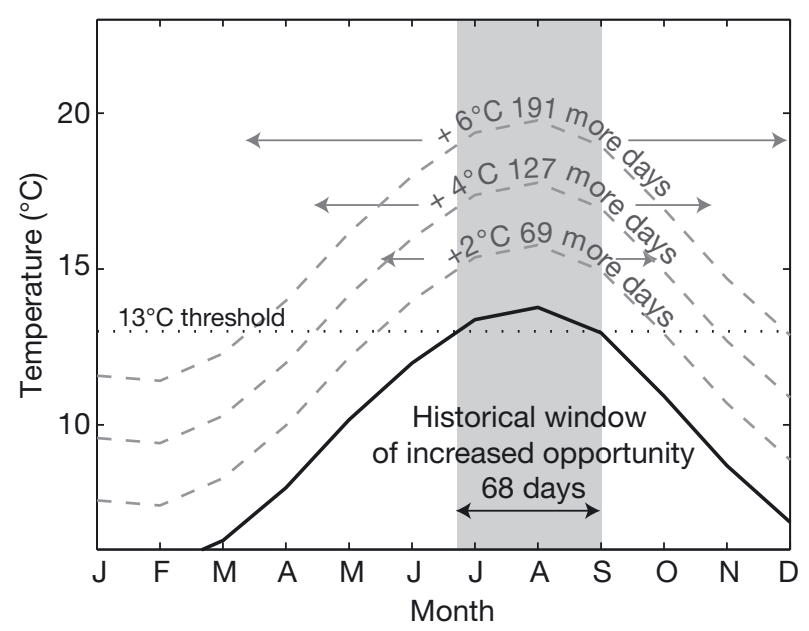

Fig. 1. Alexandrium catenella. Expansion of the annual temporal window for blooms of the saxitoxin-producing dinoflagellate in Puget Sound, Washington, USA, at projected sea surface warming levels of $+2,+4$, and $+6^{\circ} \mathrm{C}$. The species is limited to blooming at temperatures over $13^{\circ} \mathrm{C}$; with a $6^{\circ} \mathrm{C}$ average increase, the annual bloom window could expand from the historical value of $68 \mathrm{~d}$ to as long as $259 \mathrm{~d}$ (from Moore et al. 2008)

Proliferation of paralytic shellfish poisoning (PSP)producing dinoflagellates of the genus Alexandrium also tends to be seasonally and regionally specific. As described by Anderson et al. (2012, p. 29)

Overall, the Alexandrium species that have been studied in detail have proven to be remarkably resilient and capable of colonizing a wide spectrum of habitats and hydrographic regimes. It is thus of no surprise that the biogeographic range of these species has expanded in recent times and that associated PSP outbreaks remain a significant global problem.

Once cyst beds become established in a given locality, temperature may determine periods of excystment and vegetative growth (Anderson et al. 2005). Annual variability in PSP-contaminated shellfish could result from either changing seasonal incidence of toxic Alexandrium blooms, variations in toxicity by resident dinoflagellates, or a combination of both (Siu et al. 1997). Arguably, each of these scenarios could be temperature-related. Correlations between cooler temperature and enhanced Alexandrium toxicity have been reported by numerous culture and field investigations (e.g. Hall et al. 1982, Ogata et al. 1987, Cembella et al. 1988, Anderson et al. 1990). In contrast, enhanced toxicity at median or increased temperature is less common but has also been documented (Siu et al. 1997, Etheridge \& Roesler 2005, Lim et al. 2006).

Pyrodinium bahamense var. bahamense and var. compressum, 2 other PSP-producing dinoflagellates, are commonly found in tropical/sub-tropical waters (Usup et al. 2012). The western Atlantic form of $P$. bahamense was formerly thought not to produce the neurotoxins associated with PSP, but recently, accumulated saxitoxins have been found in puffer fish in the Indian River Lagoon in Florida (Landsberg et al. 2006). These results show that $P$. bahamense is a putative saxitoxin source. As with other dinoflagellates, laboratory studies have demonstrated that they have broad temperature windows, e.g. 22 to $35^{\circ} \mathrm{C}$ (Usup et al. 1995) and 23 to $37^{\circ} \mathrm{C}$ (Gedaria et al. 2007). The distribution of $P$. bahamense var. bahamense in coastal waters of Florida suggests that the minimum temperature that limits its occurrence is $20^{\circ} \mathrm{C}$ (Phlips et al. 2006). These temperature tolerances support potential climate-related range expansion (Usup et al. 2012). Although the majority of environmental variables examined influence the PSP toxin profile, not total toxin content, one study demonstrated increased toxicity at low temperature (Usup et al. 1994).

The increased abundance, geographical range expansion, and growing severity of ciguatera fish poisoning occurrences are likely indicators that several members of the benthic/epiphytic dinoflagellate genus Gambierdiscus are responding to warming sea surface temperatures and habitat transformation by concurrent spreading of the marine macroalgae with which they are associated (Morton et al. 1992, Hales et al. 1999, Chateau-Degat et al. 2005, Parsons et al. 2012). One culture study examining effects of temperature on ciguatoxins of $G$. toxicus demonstrated a positive correlation (Bomber et al. 1988). The range of Gambierdiscus is rapidly expanding along with another toxic dinoflagellate genus, Ostreopsis, which is not closely related to Gambierdiscus and produces quite different toxins, but also shares a benthic/ epiphytic lifestyle (Tindall \& Morton 1998, Rhodes 2011, Parsons et al. 2012). The majority of laboratory experiments examining temperature suggest that Ostreopsis grow more efficiently at high temperatures, but are more toxic at lower temperatures (Shears \& Ross 2009, Granéli et al. 2011, Rhodes 2011).

Growth and toxicity of other HAB dinoflagellates can also be positively or negatively related to seawater warming. Temperature affects toxicity in some diarrhetic shellfish poisoning (DSP)-producing Prorocentrum spp. (Morton et al. 1994) and Dinophysis spp. (Kamiyama et al. 2010, Tong et al. 2011). In a study by Peperzak (2003), P. micans and P. minimum doubled their growth rates in simulated warm stratified conditions. The majority of studies on yessotoxin and analogues produced by Protoceratium reti- 
culatum suggest that toxicity increases with temperature (Guerrini et al. 2007, Paz et al. 2007). The brevetoxin-producing dinoflagellate Karenia brevis, which causes mass mortality of marine life in the Gulf of Mexico, has been observed in the field between 7 and $34^{\circ} \mathrm{C}$ (Brand et al. 2012). However, optimal growth in laboratory cultures is between 22 and $29^{\circ} \mathrm{C}$ (Magana \& Villareal 2006, Vargo 2009). The closely related $K$. mikimotoi has also been found over a wide range of temperatures $\left(4\right.$ to $32^{\circ} \mathrm{C}_{i}$ Gentien 1998 , Brand et al. 2012). Toxin production in $K$. brevis demonstrates a trend of slightly higher toxicity at low temperatures that impair growth (Lamberto et al. 2004), suggesting the possibility of reduced brevetoxin impacts in a future warming ocean.

A recent 50 yr time series study in the northeast Atlantic and North Sea shows that phytoplankton community structure has shifted away from dinoflagellates, including harmful species such as some Prorocentrum spp. and non-harmful taxa such as Ceratixum fuca, and towards diatoms such as the potentially toxic Pseudo-nitzschia spp. and nonHABs such as Thalassiosira spp. (Hinder et al. 2012). The combined effects of increasing sea surface temperature and increasingly windy conditions in summer were suggested to be the main reasons for this observation. However, Hinder et al.'s (2012) results do not necessarily apply to many HAB species, since the survey focused on an open ocean phytoplankton community, and most HABs occur in estuaries or coastal waters. Local physical dynamics in these 2 regions are completely different. Nutrients are generally much more enriched in estuaries than in the open ocean, and estuaries and bays are usually less affected by wind-driven physics. Some harmful taxa are warm-water species and hence slightly increasing temperature may favor their growth, in particular many dinoflagellates. Calm winds and warmer temperatures will stratify the water column and suppress mixing long enough for motile dinoflagellates to grow and accumulate in surface waters, and hence allow them to bloom.

Recent data link harmful dinoflagellate blooms to warmer temperatures. For instance, increasing temperature stimulates blooms of the toxic dinoflagellate Alexandrium in Puget Sound in Washington state (Moore et al. 2009). A large unprecedented dinoflagellate bloom was observed in San Francisco Bay in September 2004, and one of the conditions that was thought to have caused this bloom was high air temperatures (Cloern et al. 2005). Although the study by Hinder et al. (2012) convincingly demonstrated multi-decadal changes in oceanic plankton commu- nities due to altered ocean temperature and mixing, whether climate change will similarly affect the abundance or distribution of nearshore and estuarine HABs is far from clear.

\section{Nutrients}

Future climate variations such as changing storm frequencies and wind patterns will affect coastal water column dynamics, including frequency and intensity of upwelling events, tidal mixing, and mixed layer depths (Doney et al. 2009, Hallegraeff 2010). Both warming and freshening of the surface ocean from increased precipitation will promote increased seasonal water column stratification in coastal waters (Hallegraeff 2010, Paerl \& Scott 2010), as well as increases in permanent stratification in the open ocean gyres (Gentien et al. 2005, Polovina et al. 2008). The implications of this increased stratification for HABs are likely profound, since many coastal and offshore blooms depend on vertical mixing to supply nutrients from below (Cermeño et al. 2008, Boyd et al. 2010). More rapid depletion of surface nutrients and concurrent decreases in replenishment from deeper water will likely favor pico- and nano-size species (Hallegraeff 2010). Reductions in bioavailable silicate (Goffart et al. 2002) may also lead to decreased diatom abundance (Hallegraeff 2010), which could inhibit harmful blooms in some cases (e.g. those of the toxic diatom genus Pseudo-nitzschia), and promote them in others (e.g. when non-toxic diatom species are important competitors with toxic dinoflagellates).

In a classic aquatic ecology paper, Margalef (1978) suggested that diatoms are best adapted to nutrientenriched, well-mixed water columns, while dinoflagellates dominate in stratified, more oligotrophic environments. More recently, it has been repeatedly suggested that motile species such as many harmful dinoflagellates and raphidophytes have a distinct advantage in obtaining nutrients by vertical migration (Smayda 1997, Handy et al. 2005, Hallegraeff 2010, Paerl \& Scott 2010); thus enhanced stratification could offer these groups a competitive advantage. For instance, Alexandrium tamarense cells living in N-limited waters are likely able to sustain growth and moderate toxicity if they are able to perform diel vertical migration to N-rich depths (MacIntyre et al. 1997). Along with many other genera (Gentien et al. 2005), blooms of Alexandrium are usually found subsurface under stratified conditions (Cembella \& Therriault 1989). 
The mixotrophic capabilities of many dinoflagellates (Stoecker 1999, Glibert \& Burkholder 2011) may afford these organisms even more flexibility under future stratified, low-nutrient conditions (Caron \& Hutchins in press). Growth rates of some facultatively mixotrophic harmful species increase when they are supplemented with prey (Adolf et al. 2006, Glibert et al. 2009). This alternative metabolic strategy would offer a potential for broader niches and alternative resource exploitation under both nutrient-poor and eutrophic conditions.

Of course, in many coastal and estuarine regimes, cultural eutrophication may be more important than increased stratification in determining future nutrient availability. In particular, in future climate regimes, some regions of North America are predicted to experience either more precipitation, or the same amount of precipitation delivered in fewer and thus larger pulses (IPCC 2007). This could result in heavier and more intense nutrient loading to coastal and estuarine ecosystems, and this perhaps stimulation of HAB events.

In addition to generally increased nutrient loading, coastal ecosystems can also experience unbalanced nutrient ratios from anthropogenic inputs, potentially leading to limitation by either phosphorus (P) (high N:P ratios) or nitrogen (N) (low N:P ratios) (Smayda 1997). These skewed nutrient ratios can have significant but genera-specific effects on physiological characteristics, in particular their cellular toxicity. For instance, Guerrini et al. (2007) found that yessotoxin production by the dinoflagellate Protoceratium reticulatum is stimulated by $\mathrm{P}$ limitation, but not by $\mathrm{N}$ limitation. Likewise, saxitoxin-producing members of the dinoflagellate genus Alexandrium demonstrate increased toxicity only under P limitation (Boyer et al. 1987, Anderson et al. 1990, Siu et al. 1997). In contrast, for the dinoflagellate Karlodinium veneficum, karlotoxin concentrations increase significantly under conditions of either $\mathrm{N}$ or $\mathrm{P}$ limitation (Adolf et al. 2009). In the dinoflagellate Prorocentrum lima, N and P limitation both increase cellular concentrations of the toxin okadaic acid (Vanucci et al. 2010), but in Dinophysis acuminata, okadaic acid levels increased only under $\mathrm{N}$ limitation (Johansson et al. 1996). Intracellular concentrations of domoic acid in some toxic Pseudonitzschia species are enhanced by $\mathrm{Si}$ and $\mathrm{P}$ limitation, but not by N limitation (Bates et al. 1991, Pan et al. 1996b,c). Often, the synthesis of N-rich toxins such as domoic acid and PSPs is reduced with $\mathrm{N}$ limitation (Boyer et al. 1987, Bates et al. 1991), while that of toxins containing no $\mathrm{N}$, such as yessotoxins and karlotoxins, are less dependent on the availability of this nutrient (Adolf et al. 2009).

In addition to various limiting nutrient scenarios, the chemical form or speciation of nutrients can also affect algal toxicity. The bloom-forming dinoflagellate Karenia brevis shows little response of brevetoxin production to nutrient limitation (Lekan \& Tomas 2010), but is enhanced when grown on urea versus nitrate (Shimizu et al. 1995). N speciation can also have implications for toxicity in Alexandrium spp., since saxitoxin production is enhanced when cultures are grown on ammonium as opposed to either nitrate or urea (Levasseur et al. 1995, John \& Flynn 2000, Hamasaki et al. 2001). In natural blooms of the diatom Pseudo-nitzschia, domoic acid levels increase with $\mathrm{N}$ source in the order urea > nitrate > ammonium (Armstrong Howard et al. 2007). However, a recent Pseudo-nitzschia spp. laboratory study showed that $\mathrm{N}$ sources may affect cellular domoic acid content in species- or strain-specific ways (Thessen et al. 2009). That work (op.cit.) suggests that there is no general trend regarding effects of $\mathrm{N}$ source on cellular domoic acid levels, and that it is consequently important to consider intra- and interspecies variability in ecophysiology and toxicity.

Ocean acidification may be relevant to this dependency of HAB toxicity on specific $\mathrm{N}$ sources, since low $\mathrm{pH}$ has been shown to inhibit nitrification and so could ultimately shift the speciation of the overall ocean $\mathrm{N}$ inventory away from nitrate and towards reduced species such as ammonium and organic nitrogen (Hutchins et al. 2009, Beman et al. 2011). A model of the North Sea at 1000 ppm $\mathrm{CO}_{2}$ suggests that ammonia oxidation rates could be inhibited by as much as $20 \%$, resulting in a decrease of the nitrate to total dissolved inorganic ratio by up to $10 \%$ (Blackford \& Gilbert 2007). Such a substantial shift in the chemical form of $\mathrm{N}$ supplied to phytoplankton communities under acidified conditions could potentially favor smaller organisms that are more competitive for ammonium, such as picoeukaryotes and cyanobacteria, as well as some HAB species such as dinoflagellates and raphidophytes.

\section{Solar irradiance}

Light is obviously a key factor affecting the physiological responses of all photoautotrophs, including $\mathrm{HAB}$ species. Irradiance regimes will change for primary producers in many areas of the future ocean due 
to the increased stratification and mixed layer shoaling (discussed in the 'Nutrients' section above). Phytoplankton circulating in a shallower mixed layer will necessarily be exposed to higher mean daily doses of photosynthetically active radiation (PAR; Boyd et al. 2010), as well as to more potentially deleterious ultraviolet (UV) radiation (Gao et al. 2012a; UV is considered further in the 'Interactive effects' section below).

In general, it should not be surprising that in the absence of other limiting factors, HAB growth increases with PAR, within physiologically tolerable limits. For instance, light-dependent growth kinetics occur in many species of Alexandrium (Anderson et al. 1984, Maranda et al. 1985, Ogata et al. 1987, 1989, Parkhill \& Cembella 1999, Lim et al. 2006). Laabir et al. (2011) found a positive relationship between light intensity and growth rates and biomass of a Mediterranean Alexandrium catenella isolate up to $90 \mu \mathrm{mol}$ photons $\mathrm{m}^{-2} \mathrm{~s}^{-1}$; photoinhibition was not observed until a light intensity of $260 \mu \mathrm{mol}$ photons $\mathrm{m}^{-2} \mathrm{~s}^{-1}$ was reached. Another A. catenella culture showed no sign of photoinhibition up to $800 \mu \mathrm{mol}$ photons $\mathrm{m}^{-2}$ $\mathrm{s}^{-1}$ (Carignan et al. 2002). These results support the suggestion that the genus Alexandrium is adapted to high light (Smayda 2008), which could provide it with a competitive advantage in future shallower mixed layers.

Baek et al. (2008) showed that optimal growth rates of the bloom-forming dinoflagellates Ceratium furca and C. fusus occur at irradiances ranging from 216 to $796 \mu \mathrm{mol}$ photons $\mathrm{m}^{-2} \mathrm{~s}^{-1}$. Like Alexandrium, these results indicate that Ceratium is well-adapted to intense light levels and hence has an advantage in highly transparent or shallow mixed layers (Baek et al. 2008).

Similarly, increasing light intensity stimulates the growth of the estuarine raphidophytes Heterosigma akashiwo and Chattonella subsalsa, which exhibit maximum growth rates over a light range of 100 to $600 \mu \mathrm{mol}$ photons $\mathrm{m}^{-2} \mathrm{~s}^{-1}$; no sign of photoinhibition was observed for either species even at the highest light intensity tested, $>600 \mu \mathrm{mol} \mathrm{m}{ }^{-2} \mathrm{~s}^{-1}$ (Zhang et al. 2006). These results support the suggestion that raphidophycean flagellates generally can tolerate and even prefer very high light intensities (Kahn et al. 1998). Another recent study demonstrated that light effects on the growth of $H$. akashiwo are temperature-dependent (Martinez et al. 2010). They also found differences in growth responses to light between $H$. akashiwo strains, suggesting that light could play a role in intraspecific dominance shifts and that generalizations for the whole genus may need to be made cautiously.
In contrast to these $\mathrm{HAB}$ species, there is evidence that the dinoflagellate Karenia brevis appears to be relatively low-light adapted. This species has a low light saturation point of around $65 \mu \mathrm{mol} \mathrm{m} \mathrm{m}^{-2} \mathrm{~s}^{-1}$ (Shanley \& Vargo 1993, Magana \& Villareal 2006), and its light compensation point is around 20 to $30 \mu \mathrm{mol} \mathrm{m}^{-2} \mathrm{~s}^{-1}$ (Wilson \& Collier 1955, Aldrich 1962, Eng-Wilmot et al. 1977). Brown tides (Aureococcus and Aureoumbra) are another group of HABs that benefit from low light, as both genera commonly bloom in severely light-attenuated environments (Gobler \& Sunda 2012). These 2 genera can attain nearly maximum growth rates under a light intensity of $50 \mu \mathrm{mol} \mathrm{m} \mathrm{m}^{-2} \mathrm{~s}^{-1}$ at $20^{\circ} \mathrm{C}$ (MacIntyre et al. 2004). Consistent with their low light adaption, genetic evidence for adaptation to low light was obtained from the Aureococcus genome (Gobler et al. 2011). These results suggest that both $K$. brevis and brown tides have an advantage when growing at depth, and also may have a competitive advantage during dense self-shaded blooms. This trait, however, means that they may not benefit from future increases in mean light exposures as much as many other non-HAB taxa.

Light is required for production of many algal toxins, including PSPs, domoic acid, and DSP toxins (Proctor et al. 1975, Bates et al. 1991, Pan et al. 1996a, Carneiro et al. 2009, Tong et al. 2011). Parkhill \& Cembella (1999) and Etheridge \& Roesler (2005) revealed that the highest cellular toxin levels in Alexandrium tamarense and A. fundyense were observed at light intensities between 100 and $150 \mu \mathrm{mol}$ photons $\mathrm{m}^{-2} \mathrm{~s}^{-1}$. Analysis of PSP composition in Alexandrium demonstrated that toxin composition did not vary with increasing light (Boyer et al. 1987, Cembella et al. 1987, Ogata et al. 1987, Oshima et al. 1990, Cembella \& Destombe 1996, Parkhill \& Cembella 1999, Lim et al. 2006), suggesting that light regulated the total toxin concentrations rather than changing the toxin profiles. In contrast to these observations of toxin stimulation by increasing light, an inverse relationship between cellular toxicity and light-dependent growth was also documented (Ogata et al. 1987, Hamasaki et al. 2001, Cembella 1998). There appears to be no general trend that applies to the effect of light on the production of PSPs in all Alexandrium species and strains, and in general the effect of light variation on toxicity is less remarkable compared to other factors such as temperature, salinity, and nutrients (Ogata et al. 1987, Lim et al. 2006). Thus, the responses of these dinoflagellates to any future increases in irradiance doses due to mixed layer shoaling are difficult to predict. 
The responses of toxicity to light are also complex in HAB raphidophytes. In Heterosigma, there is an inverse relationship between light-limited growth rates and toxicity (Ono et al. 2000). Conversely, hemolytic activity of Fibrocapsa japonica is positively affected by light (de Boer et al. 2009). Other studies with Chattonella marina have related light intensity positively to its ichthyotoxicity (Ishimatsu et al. 1996, Marshall et al. 2001). Similar results were also observed by Oda et al. (1997) and Marshall et al. (2001, 2005), who reported that light is also involved in the production of ROS by raphidophytes, including F. japonica.

The influence of light on the growth and toxin production of dinoflagellates has been more extensively investigated compared to toxic diatoms. Several studies have documented physiological responses of Pseudo-nitzschia spp. to light intensity (Bates et al. 1991, Whyte et al. 1995, Pan et al. 1996a, Fehling et al. 2005, Thessen et al. 2009), but only one of these described light as a basic requirement for domoic acid production (Bates et al. 1991). Domoic acid production by Pseudo-nitzschia is inhibited in darkness, but resumes soon after cultures are shifted into the light (Bates et al. 1991). Although cultures of P. seriata exposed to a long photoperiod (18 h light: $6 \mathrm{~h}$ dark) compared to a short photoperiod (9 h light: $15 \mathrm{~h}$ dark) have higher growth rates, biomass, and total domoic acid production, their cellular domoic acid content is reduced (Fehling et al. 2005).

The majority of published studies showing lightregulated growth and toxin production in HAB species have been done with laboratory cultures. Recently, however, field observations assessing the environmental factors regulating Pseudo-nitzschia blooms in the northern Gulf of Mexico have found that the mean cell toxin quotas and abundance of Pseudo-nitzschia species were strongly correlated with several factors, including high irradiance (Fig. 2C,D; MacIntyre et al. 2011).

\section{Salinity}

Altered future rainfall and climate patterns could significantly increase salinity variability in coastal areas, and especially in estuaries (Hallegraeff 2010, Paerl \& Scott 2010). Such salinity fluctuations may favor halotolerant and euryhaline organisms such as many HAB dinoflagellates and raphidophytes. For instance, many species of the dinoflagellate Prorocentrum are euryhaline in culture and in nature (Grzebyk \& Berland 1996). In a clonal culture of $P$.
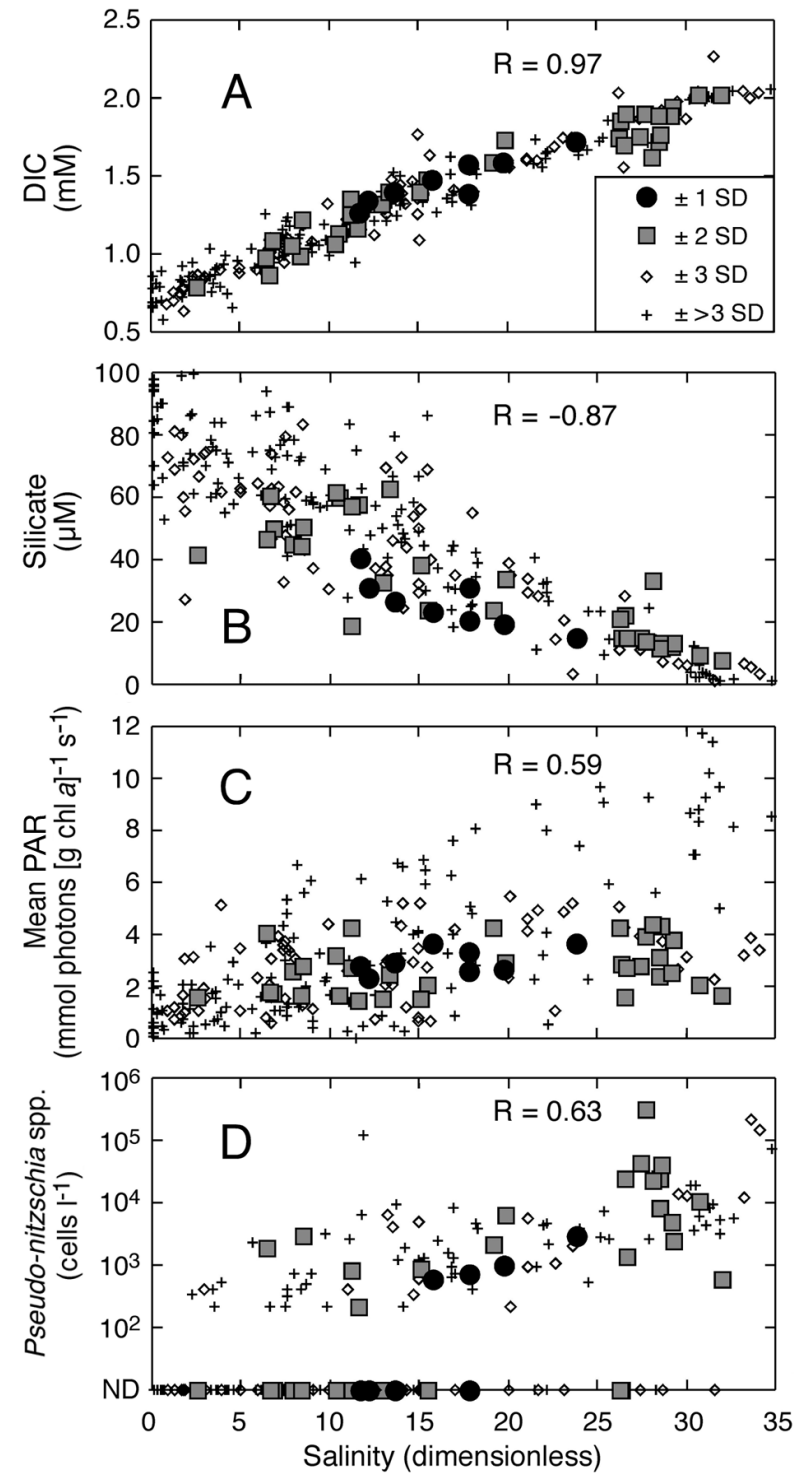

Fig 2. Pseudo-nitzschia spp. Environmental correlations with abundance of domoic acid-producing diatoms in samples in which domoic acid was detected across an estuarine salinity gradient in the Gulf of Mexico. Plotted against salinity are (A) total dissolved inorganic carbon (DIC), (B) silicate concentrations, (C) mean down-welling photosynthetically active radiation (PAR) in the water column, and (D) Pseudonitzschia spp. abundance. ND: counts that were below the limit of detection; R-values represent correlation coefficients for each entire data set (from MacIntyre et al. 2011, used by permission)

lima, growth rate and toxicity were inversely correlated with salinity (Morton et al. 1994). In the dinoflagellate Karlodinium veneficum, reduced growth rates due to low salinity significantly enhance cellular toxin quotas (Adolf et al. 2009). However, the diatom Pseudo-nitzschia multiseries demonstrates reduced growth rates and cell-normalized toxicity at 
lower salinities; at full seawater salinity, toxicity increases several fold (Doucette et al. 2008). Speciesspecific salinity-related growth tolerances have been reported by several investigators for this diatom genus (Jackson et al. 1992, Lundholm et al. 1994, 1997, Thessen et al. 2005).

Dense proliferations of Alexandrium cells normally occur in coastal zones. Consistent observations within estuaries, and the generally wide salinity tolerance of this genus, suggest that salinity is an influential growth factor (Franks \& Anderson 1992, Parkhill \& Cembella 1999, Lim \& Ogata 2005). Reported relationships between toxicity and salinity range from inverse (Grzebyk et al. 2003, Lim \& Ogata 2005) to no difference (Anderson et al. 1990) to positive (White 1978, Lim \& Ogata 2005). For instance, Grzebyk et al. (2003) reported that a clone of $A$. minutum grew most favorably at salinity 20 to 37 , but toxicity was highest at salinity 15 .

A range of responses of growth and toxicity to changing salinity has also been reported in other dinoflagellates. One study on Pyrodinium bahamense revealed a high tolerance to salinity changes, but natural blooms are usually encountered only at salinities of 20 or more (Usup et al. 2012). Guerrini et al. (2007) reported that Protoceratium reticulatum grows over a salinity range of 22 to 42 , with the highest yessotoxin concentration at salinity 32 . Paz et al. (2007) also reported that yessotoxin production decreased with increasing salinity in this species. Toxicity in this species was demonstrated to be relatively unchanged above salinity 24 , but was enhanced 3-fold at salinity 20 (Usup et al. 1994). Karenia brevis is thought to tolerate a range of salinities (18-45) but seems to grow best in full-salinity seawater (Magana \& Villareal 2006, Brand et al. 2012). However, a recent laboratory study by Errera \& Campbell (2011) demonstrated a close connection between salinity and brevetoxin production by $K$. brevis. Three of 4 clones of $K$. brevis responded to hypoosmotic shock dramatically: cellular brevetoxin quota increased by 14 -fold, while cell volume remained unchanged. This study implies that brevetoxin production by $K$. brevis may be affected by variations in salinity due to semi-daily tidal rhythms, and that this species could become more toxic if future precipitation increases result in lower salinities in the coastal regions where it blooms. $K$ mikimotoi exhibits a similar salinity tolerance of 9 to 35 (Gentien 1998, Vargo 2009, Brand et al. 2012).

Benthic and epiphytic HABs can also be affected by salinity. For instance, in Gambierdiscus, both growth and toxicity respond to salinity changes. In general, members of this genus grow optimally at or near full-strength seawater, but can tolerate mild fluctuations (Parsons et al. 2012), and toxicity is partially determined by salinity (Bomber et al. 1988, Roeder et al. 2010). The effects of salinity on the ecologically similar genus Ostreopsis are quite variable, ranging from negative to positive correlations with growth and toxicity (Pistocchi et al. 2011). A Mediterranean $O$. ovata isolate displays optimal growth rates at high salinity (36-40), but toxicity is highest at salinity 32 (Pezzolesi et al. 2012). While there is an evident lack of consistency in the responses of these various HAB species to changing salinity, species-specific increases or decreases in toxicity and growth rate are commonly reported and may become important to consider under future changing precipitation and evaporation regimes in coastal areas and estuaries.

\section{INTERACTIVE EFFECTS OF $\mathrm{CO}_{2}$ AND OTHER ENVIRONMENTAL VARIABLES ON HABS}

\section{$\mathrm{CO}_{2}$ and temperature}

As discussed above, rising temperature may increase the bloom frequencies of cyanobacteria and dinoflagellates relative to other algae such as diatoms (reviewed by Beardall et al. 2009b). Although a number of studies have determined how global warming affects various harmful species, very little is known about the effects of rising temperature in concert with rising $\mathrm{CO}_{2}$ on their physiology or ecology. To our knowledge, only 1 published study has focused on interactive effects of $\mathrm{CO}_{2}$ and temperature increases in $\mathrm{HAB}$ species. $\mathrm{Fu}$ et al. (2007) compared the combined effects of $\mathrm{CO}_{2}$ and temperature on cultures of the raphidophyte Heterosigma akashiwo and the dinoflagellate Prorocentrum minimum isolated from the same Delaware Inland Bays (USA) estuary. Maximum light-saturated photosynthetic rates $\left(P_{\text {max }}^{B}\right)$ increase in $H$. akashiwo only with simultaneous $\mathrm{CO}_{2}$ and temperature increases (Fig. 3A), whereas $P^{B}{ }_{\max }$ in $P$. minimum responds significantly to $\mathrm{CO}_{2}$ enrichment, with or without increased temperature (Fig. 3B; Fu et al. 2007). $\mathrm{CO}_{2}$ availability and temperature also have pronounced effects on cellular $\mathrm{C}$ and $\mathrm{N}$ content in H. akashiwo, but not in P. minimum. Evidently, there can be major differences in responses to combined warming and acidification even between 2 $\mathrm{HAB}$ species that commonly bloom together in the same body of water. 


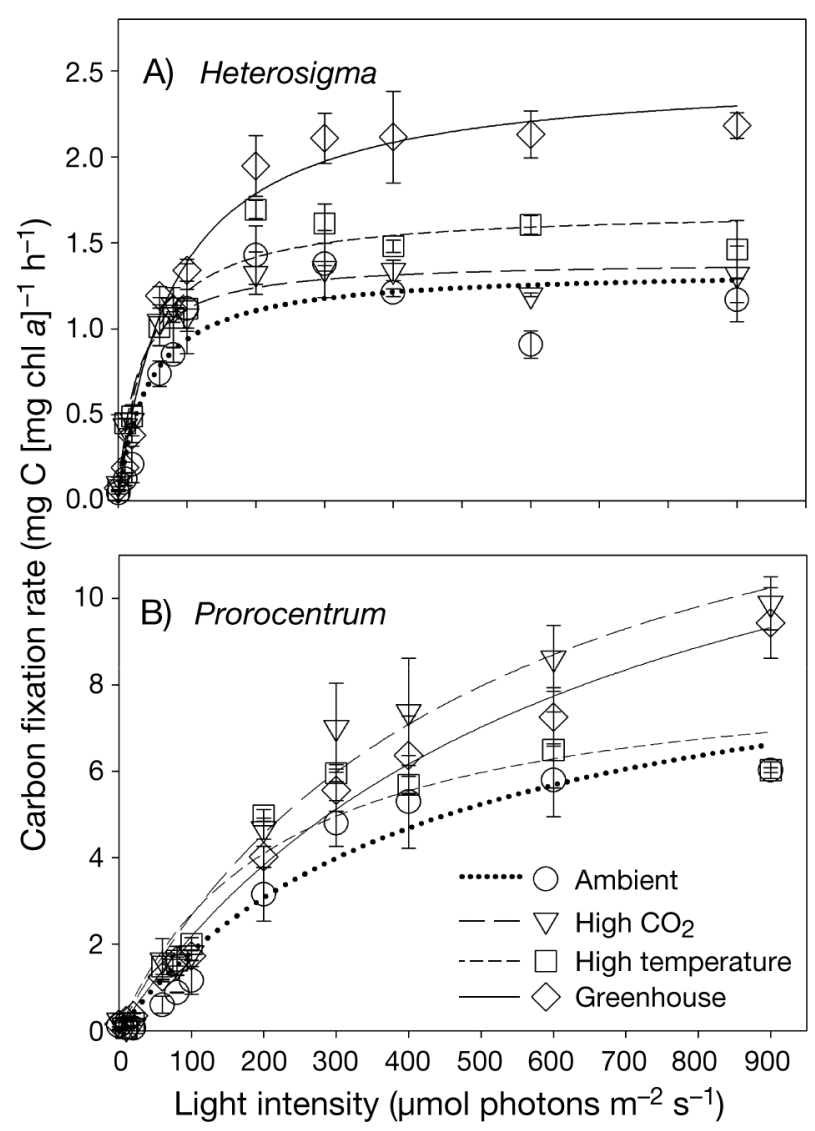

Fig. 3. Heterosigma akashiwo and Prorocentrum minimum. Photosynthesis versus irradiance curves for (A) the raphidophyte $H$. akashiwo and (B) the dinoflagellate $P$. minimum in a $\mathrm{CO}_{2}$ /temperature interaction experiment. Treatments included ambient $\left(20^{\circ} \mathrm{C}\right.$ and $\left.375 \mathrm{ppm} \mathrm{CO}_{2}\right)$, high $\mathrm{CO}_{2}\left(20^{\circ} \mathrm{C}\right.$ and $\left.750 \mathrm{ppm} \mathrm{CO}_{2}\right)$, high temperature $\left(24^{\circ} \mathrm{C}\right.$ and $375 \mathrm{ppm}$ $\left.\mathrm{CO}_{2}\right)$, and greenhouse $\left(24^{\circ} \mathrm{C}\right.$ and $\left.750 \mathrm{ppm} \mathrm{CO}_{2}\right)$. Maximum photosynthetic rates increased only in the greenhouse treatment for Heterosigma, but in both high $\mathrm{CO}_{2}$ treatments for Prorocentrum, regardless of temperature (from $\mathrm{Fu}$ et al. 2008a, used by permission)

Heterosigma akashiwo is not the only HAB species likely to benefit from a greenhouse climate regime. Our preliminary experiments with Chattonella subsalsa, another bloom-forming raphidophyte from the same Delaware Inland Bays estuary, also demonstrated enhanced growth under $\mathrm{CO}_{2}$ and temperature conditions predicted for the end of this century (Fig. 4). These 2 studies suggest that some raphidophytes may be favored by the combination of future rising $\mathrm{CO}_{2}$ and temperature, possibly more than other co-occurring HAB groups such as dinoflagellates.

In preliminary work, we have observed interactions between temperature and $\mathrm{CO}_{2}$ that strongly influenced PSP production by the marine dinoflagellate Alexandrium catenella, in a strain isolated from coastal southern California. Within 15 and $19^{\circ} \mathrm{C}$ tem-

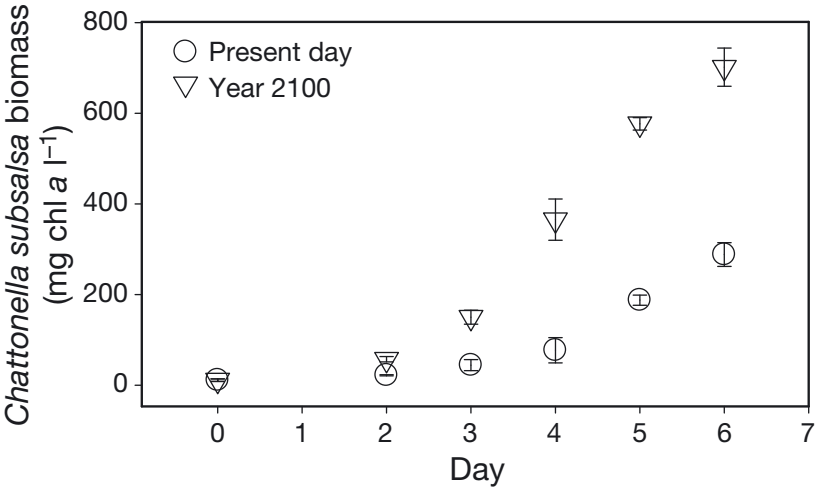

Fig. 4. Chattonella subsalsa. Growth of an estuarine harmful algal bloom raphidophyte (mean $\pm \mathrm{SD}, \mathrm{n}=3$ ) at present-day temperature and $\mathrm{pCO}_{2}\left(20^{\circ} \mathrm{C}\right.$ and $\left.375 \mathrm{ppm} \mathrm{CO}_{2}\right)$, and at levels projected for the year $2100\left(24^{\circ} \mathrm{C}\right.$ and $\left.750 \mathrm{ppm} \mathrm{CO}_{2}\right)$ (F. X. Fu \& D. A. Hutchins unpubl. data)

perature treatments, triplicate bottles were equilibrated at 2 different $\mathrm{CO}_{2}$ concentrations (380 ppm $\mathrm{pCO}_{2}$ : present day; $800 \mathrm{ppm} \mathrm{pCO}_{2}$ : future). $\mathrm{pCO}_{2}$ levels were obtained by gentle bubbling with filtered commercial gas (Tatters et al. 2012). Four treatments were used in this study: control $\left(15^{\circ} \mathrm{C}, 380 \mathrm{ppm} \mathrm{CO}_{2}\right)$; high $\mathrm{CO}_{2}\left(15^{\circ} \mathrm{C}, 800 \mathrm{ppm}\right)$; high temperature $\left(19^{\circ} \mathrm{C}\right.$, $\left.380 \mathrm{ppm} \mathrm{CO}_{2}\right)$; and 'greenhouse' $\left(19^{\circ} \mathrm{C}, 800 \mathrm{ppm}\right.$ $\mathrm{CO}_{2}$ ). Experiments used identical semicontinuous culturing methods with each species to measure temperature and $\mathrm{CO}_{2}$ effects during acclimated steadystate growth (Fu et al. 2010); saxitoxin measurements were made using HPLC (Abbott et al. 2009) with calibration standards obtained from the National Research Council of Canada (Halifax, Nova Scotia).

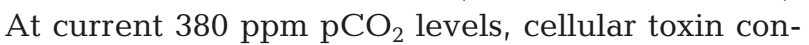
tents did not differ between temperatures, but in the high $\mathrm{pCO}_{2}$ treatment (800 ppm), the slowly growing cultures maintained at $15^{\circ} \mathrm{C}$ had cellular toxin contents that were $\sim 50 \%$ higher than those in fastergrowing cultures maintained at $19^{\circ} \mathrm{C}$ (Fig. 5). Regardless of temperature conditions, an enrichment of $\mathrm{pCO}_{2}$ significantly stimulated cellular saxitoxin equivalent contents, with an increase of $\sim 1.5$ to 2.3 times in the $800 \mathrm{ppm} \mathrm{pCO}_{2}$ treatments relative to those grown at $380 \mathrm{ppm} \mathrm{pCO}_{2}$. These results suggest that already damaging Alexandrium blooms could potentially become much more toxic under acidified conditions, but that these toxicity increases could be partially offset by simultaneously rising temperature.

Another perspective on this issue is offered by a recent study with 2 strains of Alexandrium minutum isolated from NW Spain (Flores-Moya et al. 2012). These cultures were grown for 2 yr under simulated global change conditions, including increased tem- 


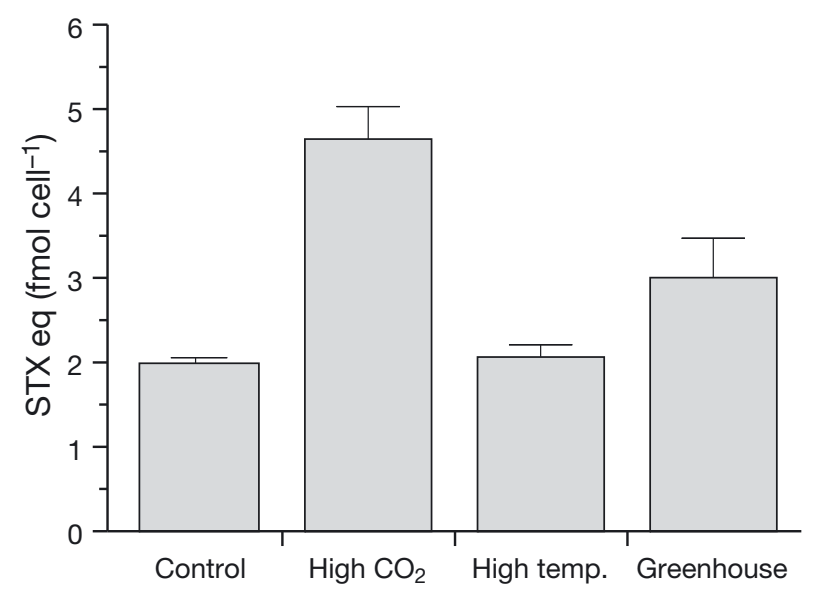

Fig. 5. Alexandrium catenella. Preliminary experiment showing cellular paralytic shellfish toxin contents (fmol cell ${ }^{-1}$ saxitoxin equivalents, STX eq) in a southern California isolate of the dinoflagellate grown at control $\left(15^{\circ} \mathrm{C}\right.$ and presentday $\mathrm{CO}_{2}$ at $\left.380 \mathrm{ppm}\right)$, high $\mathrm{CO}_{2}\left(15^{\circ} \mathrm{C}, 800 \mathrm{ppm} \mathrm{CO}_{2}\right)$, high temperature $\left.\left(19^{\circ} \mathrm{C}, 380 \mathrm{ppm} \mathrm{CO}\right)_{2}\right)$, and greenhouse $\left(19^{\circ} \mathrm{C}\right.$, $800 \mathrm{ppm} \mathrm{CO}_{2}$ ) (A. O. Tatters et al. unpubl. data)

perature (from 20 to $25^{\circ} \mathrm{C}$ ) and decreased $\mathrm{pH}$ (from 8.0 to 7.5$)$. The results suggest that long-term adaptation and acclimation to future global change may stimulate their growth rates, but effects on cellular toxicity were unpredictable due to high variance in cellular toxin contents between different cell lines (Flores-Moya et al. 2012).

Rising $\mathrm{CO}_{2}$ and temperature will not only affect the responses of phytoplankton among different major taxonomic groups, but may also elicit different responses within closely related taxa. For instance, cyanobacteria are generally thought to possess efficient CCMs, and hence they may not be especially vulnerable to carbon limitation (Badger et al. 1998). However, a culture isolate of the picocyanobacterium Synechococcus has a greater response to $\mathrm{CO}_{2}$ (controlled by bubbling) and temperature increases for many physiological parameters, compared to a closely related Prochlorococcus culture (Fu et al. 2007). However, at this time, no published studies have tested how combined $\mathrm{CO}_{2}$ and temperature increases may influence the growth and toxicity of marine and estuarine harmful cyanobacteria such as Lyngbya.

The interactive effects of $\mathrm{CO}_{2}$ and temperature on phytoplankton physiology can be species- or even strain-specific. Such differences between closely related groups can have large consequences for whole natural community changes. Currently no information is available to document the interactive effects of $\mathrm{CO}_{2}$ and temperature on natural community shifts involving HABs, but experimental results using other types of algal communities are available. For instance, in phytoplankton communities examined during the North Atlantic spring bloom, increased temperature alone promotes whole-community photosynthesis, while phytoplankton community composition is affected by both elevated $\mathrm{CO}_{2}$ and temperature (Feng et al. 2009). Similarly, the effect of rising $\mathrm{CO}_{2}$ alone on photosynthesis of phytoplankton communities was minor in the tropical North Pacific (Tortell et al. 2002) and the Bering Sea (Hare et al. 2007). However, elevated $\mathrm{CO}_{2}$ and increased temperature (the 'greenhouse' treatment) stimulates whole-community carbon fixation by 2.6 - to 3.5 -fold, and also resultes in community structure shifts from diatoms toward nanophytoplankton (Hare et al. 2007). Similar studies in estuaries and the coastal ocean are needed for HAB-dominated communities.

\section{$\mathrm{CO}_{2}$ and nutrients}

A large number of studies have investigated the influence of nutrient availability on growth and toxicity in HAB species, examining compounds such as PSPs, karlotoxins, brevetoxins, and domoic acid (see 'Nutrients' section above). However, to date, the interactive effects of changing $\mathrm{CO}_{2}$ with nutrient availability on $\mathrm{HAB}$ cell potency have been investigated only for domoic acid and karlotoxins in laboratory culture experiments (Fu et al. 2010, Sun et al. 2011, Tatters et al. 2012).

Domoic acid production increases dramatically in nutrient-limited laboratory cultures of the toxic diatoms Pseudo-nitzschia spp. as the $\mathrm{CO}_{2}$ concentration at which the cells are grown increases from $190 \mathrm{ppm}$ (glacial era levels) to $380 \mathrm{ppm}$ (approximately present-day atmospheric concentration) to $750 \mathrm{ppm}$ (projected levels for the year 2100). These trends have been documented in a $P$. multiseries isolate from eastern Canada under P limitation (Fig. 6; Sun et al. 2011), and a $P$. fraudulenta clone from southern California under Si limitation (Fig. 7; Tatters et al. 2012). These $\mathrm{CO}_{2}$-mediated toxin increases are far greater in nutrient-limited cultures than in nutrient-replete treatments, but occur under both regimes (see panel insets in Fig. 7). These studies demonstrate not only that outbreaks of amnesic shellfish poisoning events could worsen in the future high- $\mathrm{CO}_{2}$ world, but also that $\mathrm{CO}_{2}$ effects on toxicity can be influenced by changing nutrient availability.

The interactions between $\mathrm{CO}_{2}$ and nutrient availability in natural Pseudo-nitzschia communities have 


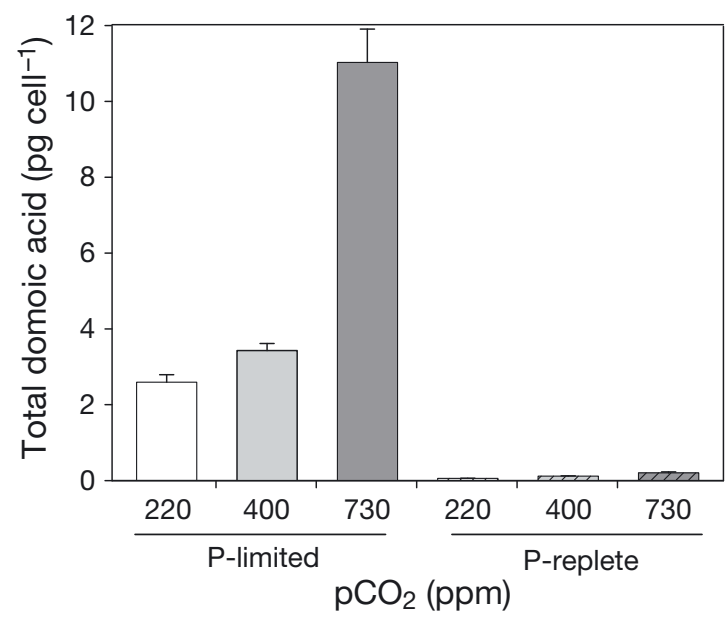

Fig. 6. Pseudo-nitzschia multiseries. Domoic acid production $($ mean $+\mathrm{SD}, \mathrm{n}=3$ ) by the Canadian east coast isolate CCMP 2708 grown at $3 \mathrm{pCO}_{2}$ levels $(220,400$, and $730 \mathrm{ppm})$ under both P-limited (open bars, $0.5 \mu \mathrm{mol} \mathrm{l}^{-1}$ ) and P-replete (crosshatched bars, $20 \mathrm{mmol} \mathrm{l}^{-1}$ ) conditions (data from Sun et al. 2011)

not been experimentally investigated. However, in Pseudo-nitzschia blooms from the Gulf of Mexico, both cell densities (Fig. 2D) and domoic acid levels (not shown) are negatively correlated with silicate concentrations (Fig. 2B) and positively correlated with dissolved inorganic carbon or $\mathrm{CO}_{2}$ (Fig. 2A; MacIntyre et al. 2011). This in situ observational study supports the culture results of Tatters et al. (2012), suggesting that domoic acid levels are enhanced in Si-limited Pseudo-nitzschia cells under high $\mathrm{CO}_{2}$ conditions.

As noted in the $\mathrm{pCO}_{2} / \mathrm{pH}$ section above, 2 prior studies examined the influence of seawater $\mathrm{pH}$ on the toxicity of Pseudo-nitzschia cultures and found that domoic acid concentrations increased instead at higher pHs (Lundholm et al. 2004, Trimborn et al. 2008). It is not clear whether these previous results and those of Sun et al. (2011) and Tatters et al. (2012) are actually conflicting, since the earlier and recent studies used different methodologies. Lundholm et al. (2004) and Trimborn et al. (2008) used nutrientreplete batch cultures grown to stationary phase, while Sun et al. (2011) and Tatters et al. (2012) used semi-continuous cultures in steady-state, nutrientlimited growth. $\mathrm{pH}$ values were adjusted by additions of $\mathrm{HCl}$ and $\mathrm{NaOH}$ in the 2 earlier studies, while $\mathrm{CO}_{2}$ or $\mathrm{pH}$ levels were obtained through bubbling the cultures with different $\mathrm{pCO}_{2}$ concentrations in the 2 newer studies. The 2 sets of studies also used different Pseudo-nitzschia species or strains, differing experimental conditions, and analytical methods.
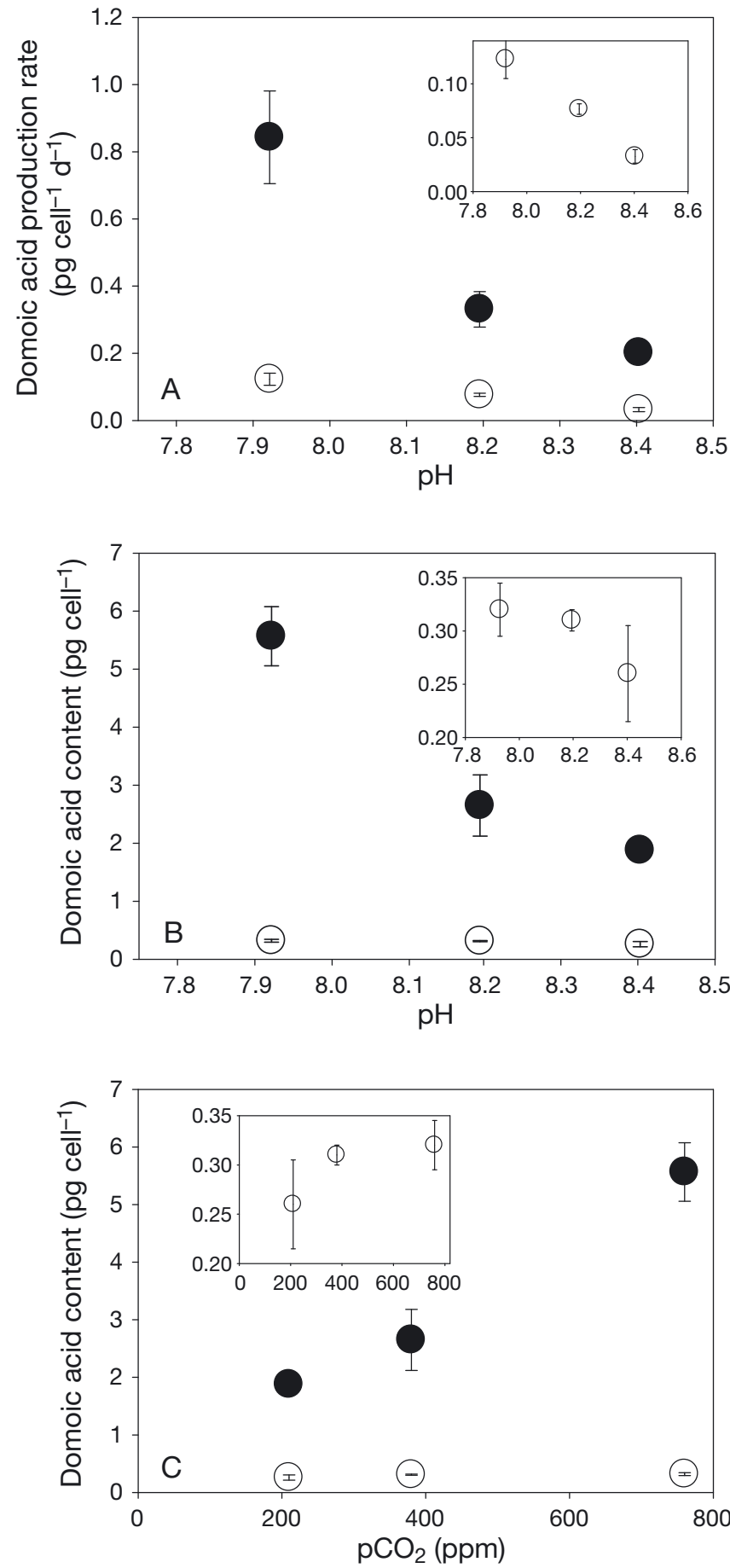

Fig. 7. Pseudo-nitzschia fraudulenta. Domoic acid production (mean $\pm \mathrm{SD}, \mathrm{n}=3$ ) by a Southern California isolate grown under $\mathrm{Si}(\mathrm{OH})_{4}$-limited $(\bullet)$ and nutrient-replete $(\mathrm{O})$ conditions at seawater $\mathrm{CO}_{2}$ concentrations of $210 \mathrm{ppm}$ (preindustrial atmospheric levels), 380 ppm (modern levels), and $760 \mathrm{ppm}$ (projected year 2100 levels). (A) Cellular domoic acid production rates (pg cell ${ }^{-1} \mathrm{~d}^{-1}$ ) versus $\mathrm{pH}$, (B) domoic acid cell contents (pg cell ${ }^{-1}$ ) versus $\mathrm{pH}$, and (C) domoic acid contents (pg cell ${ }^{-1}$ ) versus $\mathrm{pCO}_{2}$. Panel insets: nutrientreplete data with an expanded $y$-axis scale for clarity (from Tatters et al. 2012) 
Lundholm et al. (2004) also did not examine the low $\mathrm{pH}$ levels that are relevant to future ocean acidification trends. These contrasting results emphasize the need for an in-depth examination of $\mathrm{CO}_{2}$ /toxicity interactions with nutrient availability in other Pseudonitzschia species using standardized experimental protocols.

Fu et al. (2010) showed that the toxicity of the toxic estuarine dinoflagellate Karlodinium veneficum is also strongly affected by changing $\mathrm{CO}_{2}$ under nutrient-limited growth conditions. Enhanced toxin levels under $\mathrm{N}$ or $\mathrm{P}$ limitation have been reported previously in this species (Adolf et al. 2009). However, Fu et al. (2010) found that the highest levels of overall cellular toxicity by far were observed in P-limited, high- $\mathrm{pCO}_{2}$ cultures, suggesting a synergistic effect between the 2 variables (Fig. $8 \mathrm{C}$ ). This potency effect was due to a large shift in the biochemical composition of the cellular toxin pool, with cells grown under high- $\mathrm{CO}_{2}$ conditions producing much higher levels of a more toxic karlotoxin congener (Karlotoxin 1, Fig. 8A) and lower amounts of a less potent congener (Karlotoxin 2, Fig. 8B). As a result, overall cellular toxicity increased by up to $300 \%$ between 230 and $745 \mathrm{ppm} \mathrm{CO}_{2}$ in the P-limited cultures (Fig. 8C). This work demonstrates that it is important to consider the effects of future increases in atmospheric $\mathrm{CO}_{2}$ not only on levels of total cellular toxin production, but also on the entire suite of chemical congeners produced by many harmful dinoflagellate species.

\section{$\mathrm{CO}_{2}$ and solar irradiance}

To date, no published studies have shown how the interactions between increasing $\mathrm{CO}_{2}$ and PAR may affect the growth and toxin production of HABs. Gao et al. (2012b), however, demonstrate that ocean acidification reduces the ability of diatoms to cope with super-saturating PAR levels (see also Gao et al. 2012a). A few studies have examined effects of elevated $\mathrm{CO}_{2}$ in combination with UV radiation (UVR) on various phytoplankton species. UVR reaching the sea surface increased dramatically during the late 20th century due to the thinning of the stratospheric ozone layer, especially at high latitudes (Kerr \& McElroy 1993). Although the upper atmosphere concentrations of anthropogenic ozone-reactive chlorinated compounds have been reduced since the implementation of the Montreal protocol, it is still unclear when the ozone layer will fully recover (Weatherhead \& Anderson 2006). The expected enhancement of stratification in the open ocean water
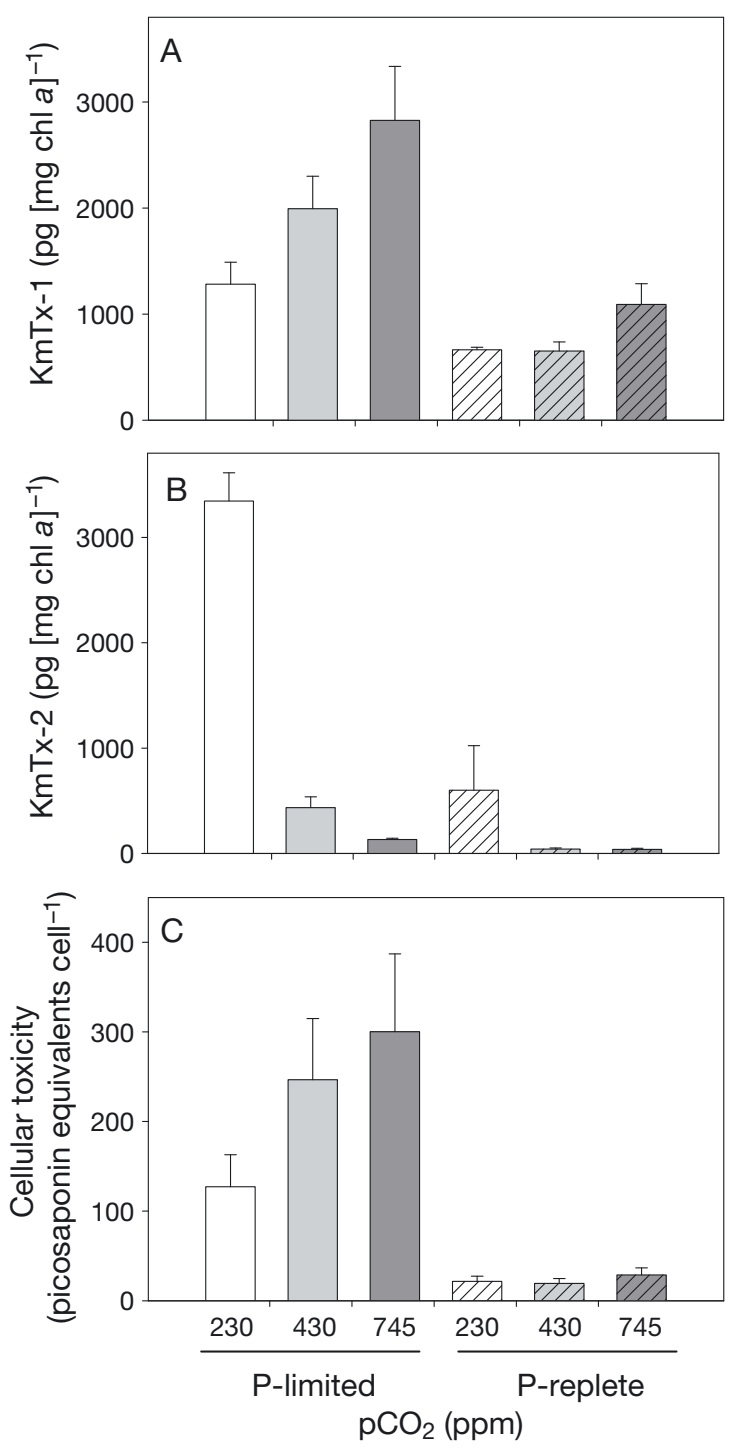

Fig. 8. Karlodinium veneficum. Chlorophyll a-normalized karlotoxin production (mean $+\mathrm{SD}, \mathrm{n}=3$ ) by estuarine harmful algal bloom dinoflagellate (isolate CCMP 2936) grown at $3 \mathrm{pCO}_{2}$ levels $(230,430$, and $745 \mathrm{ppm})$ under both P-limited (open bars, $0.5 \mu \mathrm{mol} \mathrm{l}^{-1}$ ) and P-replete (cross-hatched bars, $20 \mu \mathrm{mol} \mathrm{l^{-1 }}$ ) conditions. (A) Levels of the highly potent congener karlotoxin 1 (KmTx-1); (B) levels of the less potent congener karlotoxin $2(\mathrm{KmTx}-2)$; (C) resulting relative toxicity levels of the cultures (in picosaponin equivalents cell ${ }^{-1}$ ) (from Fu et al. 2010)

column will increase the exposure of phytoplankton in the upper mixed layer to all wavelengths of solar radiation, making deleterious exposures to UVR more likely (Gao et al. 2012a).

Mengelt \& Prézelin (2005) reported that the presence of UVA (320 to $400 \mathrm{~nm}$ ) stimulates carbon fixation by Pseudo-nitzschia-dominated communities in the Santa Barbara Channel, although UVB (280 to $320 \mathrm{~nm}$ ) photoinhibition is also observed. Their re- 
sults suggest that Pseudo-nitzschia may not be photoinhibited even in shallower portions of the water column. Because their sampling occurred during a bloom event, $\mathrm{CO}_{2}$ concentrations were likely decreasing rapidly. They suggested that exposure to UVA may increase extracellular CA activity to help maintain higher intracellular $\mathrm{CO}_{2}$ levels, despite reduced external $\mathrm{CO}_{2}$.

Sobrino et al. (2005) demonstrated that UVR sensitivity showed different responses to increased $\mathrm{CO}_{2}$ levels in 2 marine picoplanktonic eukaryotes with similar morphology but different CCMs. The 2 marine picoplankters Nannochloropsis gaditana and Nannochloris atomus were grown with constant aeration in air containing 0.03 and $1 \% \mathrm{CO}_{2}$. The former species, which relies on bicarbonate uptake for photosynthesis, shows decreased sensitivity to UVR after growing for $4 \mathrm{~d}$ under elevated $\mathrm{CO}_{2}$ conditions. In contrast, $N$. atomus, a species with active $\mathrm{CO}_{2}$ transport, shows similar sensitivity to UVR with and without supplemental $\mathrm{CO}_{2}$. These studies do not verify the potential effect of UVR on CCMs, but suggest that differences in UVR sensitivity related to external $\mathrm{CO}_{2}$ concentrations can affect taxonomic composition in open ocean algal communities. Whether this might apply to estuarine and coastal HAB assemblages has not yet been determined.

Studies with the diatom Thalassiosira pseudonana grown at $2 \mathrm{pCO}_{2}$ levels (380 versus 1000 ppm, obtained by bubbling) also have shown that the presence of UVR may affect $\mathrm{CO}_{2}$ uptake more than that of $\mathrm{HCO}_{3}{ }^{-}$(Sobrino et al. 2008). With another diatom, Skeletonema costatum, Wu \& Gao (2009) found that the presence of UV promotes external CA activity as a result of enhanced $\mathrm{CO}_{2}$ supply. They suggested that this helps cells avoid UV-induced photoinhibition of photosynthesis. Rising $\mathrm{CO}_{2}$ stimulates the growth of $T$. pseudonana regardless of exposure to UVR, but the presence of UVR does not affect its growth (Sobrino et al. 2008). Future work is necessary to determine whether the observations of these diatom studies can be applied to harmful diatoms such as toxic Pseudo-nitzschia spp., or to other HAB groups such as dinoflagellates and raphidophytes.

Chen \& Gao (2012) focused on the interactive effects of UV and ocean acidification on the photosynthetic performance of the HAB species Phaeocystis globosa. The major finding of this study was that the effect of $\mathrm{CO}_{2}$ on physiological responses, including growth rates and photochemical efficiency, is dependent on light levels (Chen \& Gao 2011). Under high light levels, enrichment with $\mathrm{CO}_{2}$ inhibits the growth of $P$. globosa with or without UVA and UVB, but the presence of either type of UVR further inhibits its growth (Fig. 9). When $\mathrm{CO}_{2}$ and UVA are combined, the effects are synergistically magnified. In contrast to its responses to UVA, UVB exposure always inhibits $P$. globosa growth regardless of the light levels and $\mathrm{CO}_{2}$ conditions. Enrichment with $\mathrm{CO}_{2}$ imposes a significant but minor negative effect of UVB and UVA on growth.

Another recent study investigated the combined effects of $\mathrm{CO}_{2}$ and PAR on Phaeocystis globosa, isolated from the North Sea (Hoogstraten et al. 2012). Their study showed that the physiological effect of $\mathrm{CO}_{2}$ is dependent on light conditions. The growth rates of high-light cultures decrease with increasing $\mathrm{CO}_{2}$ levels, while photosynthetic efficiency increases with increasing $\mathrm{CO}_{2}$. However, no $\mathrm{CO}_{2}$ effect is observed in light-limited cultures. Together with the
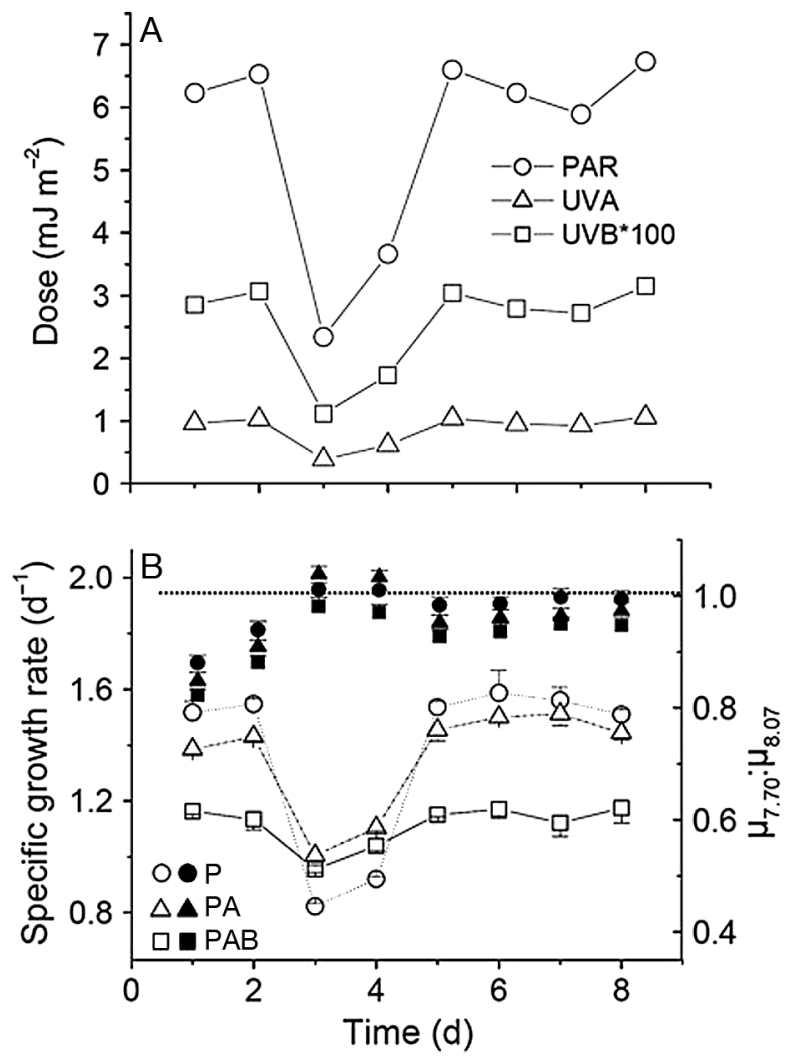

Fig. 9. Phaeocystis globosa. Effects of solar irradiance on growth of harmful algal bloom prymnesiophyte. (A) Daily doses of solar photosynthetically active radiation (PAR), ultraviolet radiation A (UVA, 315-400 nm), or ultraviolet radiation B (UVB, 280-315 nm) during the experimental period of 1 to 8 May 2009. (B) Specific growth rates of cultures grown at $\mathrm{pH} 8.07$ (open symbols) and the ratios (mean $+/-\mathrm{SD}, \mathrm{n}=3$ ) of the specific growth rates at $\mathrm{pH} 7.70$ to those at $\mathrm{pH}$ 8.07 (7.70:8.07; solid symbols), under solar PAR (P), PAR + UVA (PA), or PAR + UVA + UVB (PAB), respectively (from Chen \& Gao 2011, used by permission) 
observations of Chen \& Gao (2011), this study indicates that $P$. globosa may not be well suited to grow under expected future ocean conditions of higher PAR and UV.

No information is currently available to make a clear statement about how interactions between UVR and $\mathrm{CO}_{2}$ may affect possibly the most important physiological trait of many HAB species: toxin production. If the presence of UVB inhibits growth and photosynthesis, toxin production may be stimulated since it is often thought that toxicity is stimulated by growth-limiting conditions. If the results of Chen \& Gao (2011) and Sobrino et al. (2008), suggesting that phytoplankton are more sensitive to UVR under high $\mathrm{CO}_{2}$ conditions, are representative of HAB groups in general, toxicity may increase in the future ocean. However, the presence of moderate doses of UVA will often stimulate algal growth and carbon fixation, thus potentially counteracting this phenomenon. Algae will likely experience stronger doses of UVR as well as PAR in the future ocean, due to shallower mixed layers. Thus 3-way interactions among PAR, UVR, and $\mathrm{CO}_{2}$ will exert combined effects on the physiological responses of HABs. These alternate scenarios for toxin effects from $\mathrm{CO}_{2}$ and UVR should be examined in future work.

\section{FUTURE DIRECTIONS}

The interactive global change effects on HABs may differ significantly between marine regimes. For instance, $\mathrm{CO}_{2}$ sources, levels, and trends are likely to be quite different for estuarine, coastal, and offshore bloom events. Many freshwater-influenced estuarine systems lack robust carbonate buffer systems, and hence tend to have relatively low alkalinity and bicarbonate concentrations. In contrast, marine systems have significant pools of bicarbonate accessible to phytoplankton. Due to these chemical differences, the possible role of $\mathrm{CO}_{2}$ availability in influencing estuarine versus oceanic HAB ecology remains to be extensively investigated. Recently, Nielsen et al. (2012) investigated the effect of $\mathrm{pH}$ manipulated by additions of acid and base on an estuarine plankton community in the Derwent River estuary, Tasmania, Australia. pH effects on community structure (which included diatoms and dinoflagellates) were not observed across a pH range between 8.0 and 7.7. They pointed out that large fluctuations in seasonal and diurnal $\mathrm{pH}$ (ranging from 7.5 to 9.6) and in salinity levels in estuaries have selected phytoplankton assemblages in these regimes to tolerate a broad range of water chemistries, and hence they may not be affected by changes in $\mathrm{pH}$ within the range expected for the next $100 \mathrm{yr}$.

Coastal upwelling regions where organisms such as Pseudo-nitzschia bloom are especially vulnerable to ocean acidification, since anthropogenic $\mathrm{CO}_{2}$ can augment already naturally elevated $\mathrm{pCO}_{2}$ in upwelled water (Feely et al. 2008). In addition, coastal eutrophication and resulting suboxia or hypoxia can also strongly elevate regional $\mathrm{pCO}_{2}$ (Hales et al. 2005, Cai et al. 2011). Nutrient and light trends are also likely to be regime-specific. For instance, the commonly assumed trends of higher light exposures and reduced nutrient supplies for phytoplankton due to enhanced stratification may apply largely to the open ocean. In contrast, expected continuing future increases in anthropogenic eutrophication of estuaries are likely to result in opposite trends, with simultaneous increases in nutrient concentrations and decreases in available light due to higher turbidity. Thus, rising $\mathrm{pCO}_{2}$ and acidification will interact with other crucial environmental variables in varying ways for future $\mathrm{HAB}$ events in different types of marine ecosystems.

Many of these ocean acidification and climate change effects will manifest themselves through competition-related changes in algal community structure. Rising $\mathrm{CO}_{2}$ and temperature in concert with irradiance changes and increased eutrophication are likely to affect the ecological dominance of groups such as raphidophytes and dinoflagellates relative to competing non-harmful species. These global change effects may also favor particular HAB species over others. We tested whether $\mathrm{CO}_{2}$ availability could affect interspecific competition between 2 HAB dinoflagellates, Karlodinium veneficum and Prorocentrum minimum, isolated from the same estuary (Delaware Inland Bays). For this, we carried out a simple batch culture competition experiment in which the 2 species were inoculated at a 1:1 ratio (cell:cell) into nutrient-replete medium and grown for $10 \mathrm{~d}$ at $3 \mathrm{pCO}_{2}$ levels $(190,380$, and $750 \mathrm{ppm})$. K. veneficum growth rates (Fig. 10A) and biomass (Fig. 10B) responded positively to increasing $\mathrm{pCO}_{2}$, whereas those of $P$. minimum did not. At the end of the experiment, ratios of $K$. veneficum to $P$. minimum cells were still $\sim 1: 1$ in the low $\mathrm{pCO}_{2}$ treatment, but had increased incrementally to $\sim 3: 1$ in the high $\mathrm{pCO}_{2}$ replicates (Fig. 10C). These differing responses may reflect their different CCM efficiencies, but this hypothesis will require further work to verify. Regardless of the reason for this outcome, our artificial HAB community experiment suggests that $\mathrm{pCO}_{2}$ may be 1 factor 

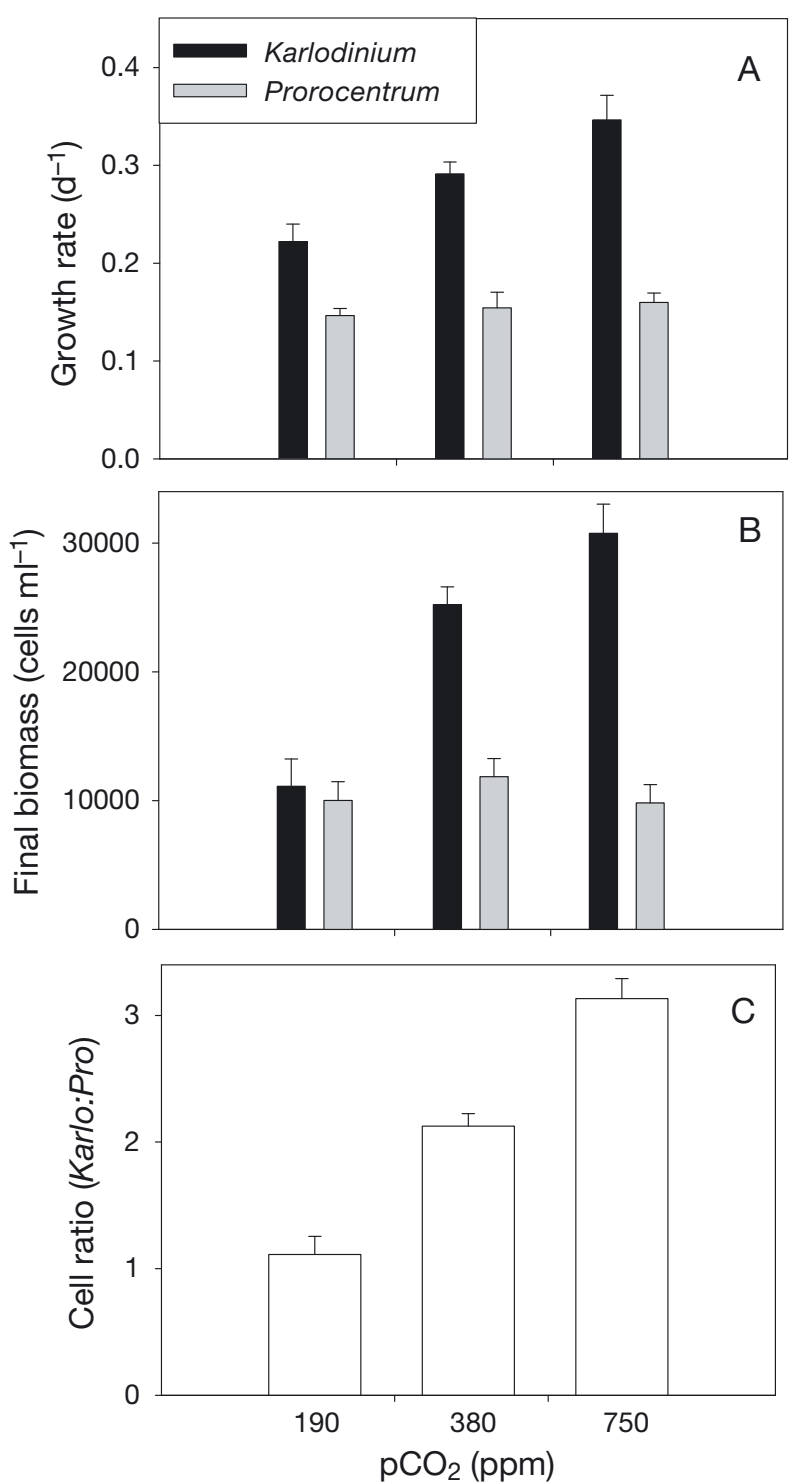

Fig. 10. Karlodinium veneficum and Prorocentrum minimum. Outcome of an ocean acidification interspecific competition experiment using mixed cultures of the dinoflagellates $K$. veneficum (black bars) and P. minimum (grey bars), isolated from the same estuary in Delaware Inland Bays, USA, at various $\mathrm{CO}_{2}$ concentrations. Mean $(+\mathrm{SD}, \mathrm{n}=3)(\mathrm{A})$ growth rates $\left(\mathrm{d}^{-1}\right)$ during the last $10 \mathrm{~d}$ of the experiment, (B) final biomass (cells $\mathrm{ml}^{-1}$ ), and (C) final abundance ratios (cell:cell) (F. X. Fu \& D. A. Hutchins unpubl. data)

(among many) determining the outcome of interspecific competition in mixed natural assemblages. The dominance of toxic $K$. veneficum over non-toxic $P$. minimum at high $\mathrm{pCO}_{2}$ could be due to $\mathrm{pCO}_{2}$ induced karlotoxin (Fu et al. 2010) inhibiting the growth of $P$. minimum. In a similar vein but between more closely related taxa, Davis et al. (2009) showed that toxic populations of the freshwater harmful cyanobacterium Microcystis can outcompete non- toxic ones at higher temperatures. Consequently, the effects of global climate change on toxin production may be important to understand in order to explain inter- and intraspecific competitive interactions within $\mathrm{HAB}$ communities in a range of aquatic ecosystems.

An emerging ocean acidification issue with potentially serious environmental implications is the new evidence that elevated $\mathrm{pCO}_{2}$ along with nutrient limitation greatly increases the cell-specific toxicity of some HAB species, including the dinoflagellate Karlodinium veneficum (Fig. 8; Fu et al. 2010) and some Pseudo-nitzschia spp. diatoms (Figs. 6 \& 7; Sun et al. 2011, Tatters et al. 2012). Our preliminary work with the dinoflagellate Alexandrium catenella shows that saxitoxin levels are greatly stimulated by ocean acidification as well (Fig. 5). These early results suggesting that toxin production can be regulated by $\mathrm{CO}_{2}$ or $\mathrm{pH}$ raise an alarming question: Will harmful algal blooms become more toxic in the future ocean? New studies are needed that encompass a broad range of harmful taxonomic groups, and that include physiological measurements along with examinations of gene and protein expression patterns with an eye towards identifying $\mathrm{CO}_{2}$ - and toxin-responsive genes for future follow-up work.

These new studies with multiple diatom and dinoflagellate species suggest a possible general principle of toxic HAB responses to ocean acidification: that the combination of low $\mathrm{pH}$ and growth limitation strongly stimulates their cellular toxin levels. This common physiological response may be shared by species from divergent taxonomic groups, and occurs when growth is limited by a variety of different nutrients, or by other environmental factors such as lower temperatures. The literature on algal toxins already highlights a generalized 'growth rate hypothesis,' in that limitation by nutrients or other factors often promotes higher toxin levels in many HAB species (Bates et al. 1991, Cembella 1998, Pan et al. 1998, Maldonado et al. 2002, Granéli \& Flynn 2006, Lim et al. 2006, Mitra \& Flynn 2006, Sunda et al. 2006, Adolf et al. 2009, Fu et al. 2010), as long as the limiting resource is not directly required for toxin synthesis (e.g. light energy or nitrogen in some cases). Thus, toxins may increase in slowly dividing cells at least partly due to the availability of a supply of 'excess' fixed carbon and photosynthetically-derived energy that can be directed into toxin precursors. Of course, any roles that toxins may play in reducing grazing mortality (Waggett et al. 2008, 2012), facilitating supplemental prey capture (Adolf et al. 2007, Sheng et al. 2010), or obtaining limiting nutrients such as iron (Maldonado et al. 2002, Wells et al. 2005), also 
become increasingly important to the HAB species when growth rates are severely limited. Our new work suggests that when elevated $\mathrm{pCO}_{2}$ is also incorporated, this growth limitation effect on toxin production is tremendously exacerbated.

It is instructive in this respect to consider the large body of previous work on the effects of changing $\mathrm{pCO}_{2}$ on secondary metabolism in terrestrial plants. The major consensus is that plant secondary metabolites increase with higher $\mathrm{CO}_{2}$ levels (Schonhof et al. 2007, Ziska et al. 2008, Ghasemzadeh \& Jaafar 2011, Ibrahim \& Jaafar 2011). Since most known algal toxins, including domoic acid, saxitoxins, brevitoxins, and karlotoxins, are classified as secondary metabolites, it should not be entirely surprising that increased $\mathrm{CO}_{2}$ levels can result in higher toxin cell quotas. The specific mechanism for this increase would be likely dependent on the class of toxins. For lipophilic toxins such as karlotoxins and yessotoxins, this could result from increased glycolate levels (the starter unit for toxin synthesis; Yamazaki et al. 2011), allowing more fixed carbon to be diverted to the toxin machinery. A major cellular source of glycolate is photorespiration (Spencer \& Togasaki 1981); however, it might be expected that this source would be reduced when ambient $\mathrm{CO}_{2}: \mathrm{O}_{2}$ ratios are high, and so this does not appear to be consistent with the observed trends in lipophilic toxin synthesis under acidified conditions. However, another study with a freshwater green alga showed that glycolate production rates were 15 to 20 times higher in elevated $\mathrm{CO}_{2}$-grown cells relative to air-grown cells (de Veau \& Burris 1989).

A similar 'high $\mathrm{CO}_{2}$ subsidy' argument can be made for hydrophilic toxins such as domoic acid (Ramsey et al. 1998) and saxitoxin (Srivastava et al. 2011) with regard to their biosynthetic precursors (e.g. acetate and arginine). Of course, an alternate hypothesis is that lowered seawater $\mathrm{pH}$ directly affects the activity of crucial enzymes in toxin biosynthetic pathways and hence synthesis; external $\mathrm{pH}$ decreases can indeed affect intracellular $\mathrm{pH}$ in several phytoplankton species (Dason et al. 2004, Suffrian et al. 2011). In order to mechanistically understand the future impacts of toxic algal blooms in a high $\mathrm{CO}_{2}$ ocean, more studies should be focused on distinguishing between these 2 possible causes: direct $\mathrm{pH}$ effects on biosynthetic pathways, and indirect stimulation of toxin synthesis by a high $\mathrm{CO}_{2}$ subsidy.

The potential impacts on the growth, toxin production, and community structure of harmful algae from increasing $\mathrm{CO}_{2}$, either alone or in conjunction with other variables, are currently poorly understood. So far, however, interactive global change effects have been examined in very few organisms. Physiological responses of dinoflagellates to even $\mathrm{pCO}_{2} / \mathrm{pH}$ shifts alone have been examined only for a handful of species (Rost et al. 2006, Fu et al. 2008a). Our ability to predict the long-term synergistic effects of climate change and ocean acidification on HAB and competing non-harmful species depends to a large extent on understanding their basic physiological and growth responses under changing conditions of $\mathrm{CO}_{2}$, temperature, irradiance, salinity, and nutrients. Some modeling work based on laboratory and field studies has attempted to predict how HABs may respond to future rising temperature (Peperzak 2003, 2005, Moore et al. 2008, 2011). For truly predictive capabilities, additional modeling studies will be necessary, which incorporate rising $\mathrm{CO}_{2}$ along with all of the other relevant global change factors as they affect growth and toxicity of harmful species.

Even less is known about the effects on HAB species of changing 'bottom-up' variables such as $\mathrm{pCO}_{2}$ and temperature when combined with altered 'top-down' controls such as microzooplankton herbivory. Aside from direct grazing effects on HAB mortality, indirect interactions between prey availability and a changing physical and chemical environment could be especially significant for mixotrophic species, such as many dinoflagellates (Caron \& Hutchins in press). Rising $\mathrm{CO}_{2}$ or interactions between $\mathrm{CO}_{2}$ and temperature have a significant effect on microzooplankton communities, abundances, and grazing rates in the North Atlantic spring bloom (Rose et al. 2009). These findings emphasize the importance of determining how $\mathrm{CO}_{2}$ and other climate variables affect trophic interactions in marine regimes where HABs are a major environmental issue.

The validity of extrapolating short-term experiments with natural HAB communities or laboratory cultures to long-term ecosystem trends needs to be explored. Incubation experiments examining responses to $\mathrm{CO}_{2}$ alone and in concert with other global change variables typically cover only a few generations, so it is hard to predict whether they accurately reflect likely future decadal- or century-scale trends in nature. Most of the published high- $\mathrm{CO}_{2}$ experiments have placed present-day phytoplankton immediately into a high- $\mathrm{CO}_{2}$ environment, and then analyzed how they respond after a given acclimatization time, which is usually shorter for field and longer for culture experiments. An exception to this is the recent study of Flores-Moya et al. (2012), which examined acclimation and adaptation to warming 
and acidification in dinoflagellates over a $2 \mathrm{yr}$ period; more studies of this sort are needed. Marine phytoplankton have large population sizes and relatively fast generation times, which means that they have a high probability of being able to adapt to ongoing environmental changes. Such potential long-term evolutionary changes in response to gradually changing $\mathrm{pCO}_{2}$ and temperature may be quite likely, complicating the interpretation of short-term studies using abruptly modified environments. For instance, the rate of environmental change affects the physiological and possibly adaptive responses of the model alga Chlamydomonas to increasing $\mathrm{CO}_{2}$ (Collins \& de Meaux 2009). The rate of change of environmental variables will likely affect responses of all phytoplankton, including HAB species, to future anthropogenic ocean acidification and climate change. The challenge for marine scientists will be to understand and accurately predict the responses of harmful algal groups to all of the many interacting factors to which they must adapt in a rapidly changing ocean.

Acknowledgements. We thank our experimental collaborators J. Sun, A. Place, K. Coyne, C. Breene, Y. Lou, and Y. Zhang, as well as L. Flewelling and A. Grandholm for help with analyses of paralytic shellfish poisoning toxins. This study was supported by US National Science Foundation grants OCE 0722337, 0825319, 0850730, 0962309, and 1143760, and by funding from USC Sea Grant.

\section{LITERATURE CITED}

Abbott JP, Flewelling LJ, Landsberg JH (2009) Saxitoxin monitoring in three species of Florida puffer fish. Harmful Algae 8:343-348

Adolf JE, Stoecker DK, Harding LW Jr (2006) The balance of autotrophy and heterotrophy during mixotrophic growth of Karlodinium micrum (Dinophyceae). J Plankton Res 28:737-751

- Adolf JE, Krupatkina D, Bachvaroff TR, Place AR (2007) Karlotoxin mediates grazing of Oxyrrhis marina on strains of Karlodinium veneficum. Harmful Algae 6:400-412

Adolf JE, Bachvaroff TR, Place AR (2009) Environmental modulation of karlotoxin levels in strains of the cosmopolitan dinoflagellate Karlodinium veneficum (Dinophyceae). J Phycol 45:176-192

Aldrich DV (1962) Photoautotrophy in Gymnodinium breve Davis. Science 137:988-990

> Anderson DM, Kulis DM, Binder BJ (1984) Sexuality and cyst formation in the dinoflagellate Gonyaulax tamarensis cyst yield in batch cultures. J Phycol 20:418-425

> Anderson DM, Kulis DM, Sullivan JJ, Hall S, Lee C (1990) Dynamic of physiology of saxitoxin production by the dinoflagellates Alexandrium spp. Mar Biol 104:511-524

> Anderson DM, Glibert PM, Burkholder JM (2002) Harmful algal blooms and eutrophication: nutrient sources, composition, and consequences. Estuaries 25:704-726

Anderson DM, Stock CA, Keafer BA, Bronzino Nelson A, Thompson B, McGillicuddy DJ (2005) Alexandrium fundyense cyst dynamics in the Gulf of Maine. Deep-Sea Res II 52:2522-2542

- Anderson DM, Alpermann TJ, Cembella AD, Collos Y, Masseret E, Montresor M (2012) The globally distributed genus Alexandrium: multifaceted roles in marine ecosystems and impacts on human health. Harmful Algae 14:10-35

Anning T, Harris G, Geider RJ (2001) Thermal acclimation in the marine diatom Chaetoceros calcitrans (Bacillariophyceae). Eur J Phycol 36:233-241

Armstrong Howard MD, Cochlan WP, Ladizinsky N, Kudela RM (2007) Nitrogenous preference of toxigenic Pseudonitzschia australis (Bacillariophyceae) from field and laboratory experiments. Harmful Algae 6:206-217

Badger MR, Andrews TJ, Whitney SM, Ludwig M, Leggat W, Price DG (1998) The diversity and coevolution of Rubisco, pyrenoids, and chloroplast-based $\mathrm{CO}_{2}$-concentrating mechanisms in algae. Can J Bot 76:1052-1071

Baek SH, Shimode S, Kikuchi T (2008) Growth of dinoflagellates, Ceratium furca and Ceratium fusus in Sagami Bay, Japan: the role of temperature, light intensity and photoperiod. Harmful Algae 7:163-173

> Barron JA, Bukry D, Field D (2010) Santa Barbara Basin diatom and silicoflagellate response to global climate anomalies during the past 2200 years. Quat Int 215: $34-44$

> Bates SS, de Freitas ASW, Milley JE, Pocklington R, Quilliam MA, Smith JG, Worms J (1991) Controls on domoic acid production by the diatom Nitzschia pungens f. multiseries in culture: nutrients and irradiance. Can J Fish Aquat Sci 48:1136-1144

Bates SS, Garrison DL, Horner RA (1998) Bloom dynamics and physiology of domoic-acid-producing Pseudo-nitzschia species. In: Anderson DM, Cembella AD, Hallegraef GM (eds) Physiological ecology of harmful algal blooms. NATO ASI Series, Vol G41. Springer-Verlag, Berlin, p 267-292

$>$ Beardall J, Sobrino C, Stojkovic S (2009a) Interactions between the impacts of ultraviolet radiation, elevated $\mathrm{CO}_{2}$, and nutrient limitation on marine primary producers. Photochem Photobiol Sci 8:1257-1265

> Beardall J, Stojkovic S, Larsen S (2009b) Living in a high $\mathrm{CO}_{2}$ world: impacts of global climate change on marine phytoplankton. Plant Ecol Divers 2:191-205

Beman JM, Chow CE, King AL, Feng Y and others (2011) Global declines in oceanic nitrification rates as a consequence of ocean acidification. Proc Natl Acad Sci USA 108:208-213

Bird CJ, Wright JLC (1989) The shellfish toxin domoic acid. World Aquacult 20:40-41

> Blackford JC, Gilbert FJ (2007) pH variability and $\mathrm{CO}_{2}$ induced acidification in the North Sea. J Mar Syst 64: 229-241

> Bomber JW, Guillard RL, Nelson WG (1988) Roles of temperature, salinity, and light in seasonality, growth, and toxicity of ciguatera-causing Gambierdiscus toxicus Adachi et Fukuyo (Dinophyceae). J Exp Mar Biol 115:53-65

Bopp L, Monfray P, Aumont O, Dufresne JL and others (2001) Potential impact of climate change on marine export production. Global Biogeochem Cycles 15:81-99

Boyd PW, Doney SC (2003) The impact of climate change and feedback processes on the ocean carbon cycle. In: Fasham MJR (ed) Ocean biogeochemistry-the role of the ocean carbon cycle in global change. Springer-Verlag, Berlin, p 157-193

Boyd PW, Doney SC, Strzepek R, Dusenberry J, Lindsay K, 
Fung I (2008) Climate-mediated changes to mixed-layer properties in the Southern Ocean: assessing the phytoplankton response. Biogeosciences 5:847-864

Boyd PW, Strzepek R, Fu FX, Hutchins DA (2010) Environmental control of open ocean phytoplankton groups: now and in the future. Limnol Oceanogr 55:1353-1376

Boyer GL, Sullivan JJ, Andersen RA, Harrison PJ, Taylor FJR (1987) Effects of nutrient limitation on toxin production and composition in the marine dinoflagellate Protogonyaulax tamarensis. Mar Biol 96:123-128

Brand LE, Campbell L, Bresnan E (2012) Karenia: the biology and ecology of a toxic genus. Harmful Algae 14: 156-178

Buck KR, Uttal-Cooke L, Pilskaln CH, Roelke DL and others (1992) Autecology of the diatom Pseudonitzschia australis, a domoic acid producer, from Monterey Bay, California. Mar Ecol Prog Ser 84:293-302

> Cai WJ, Hu X, Huang WJ, Murrell MC and others (2011) Acidification of subsurface coastal waters enhanced by eutrophication. Nat Geosci 4:766-770

Caldeira K, Wickett ME (2003) Oceanography: anthropogenic carbon and ocean $\mathrm{pH}$. Nature 425:365

Carignan MO, Montoya NG, Carreto JI (2002) Long-term effects of ultraviolet radiation on the composition of pigment and mycosporine-like amino acids (MAAs) composition in Alexandrium catenella. In: Arzul G (ed) Aquaculture, environment and marine phytoplankton. Proceedings of a Symposium held in Brest, 21-23 May 2001. IFREMER Actes Colloq 34:191-207

Carneiro RL, dos Santos MEV, Pacheco ABF, Azevedo SMFDE (2009) Effects of light intensity and light quality on growth and circadian rhythm of saxitoxins production in Cylindrospermopsis raciborskii (Cyanobacteria). J Plankton Res 31:481-488

Caron DA, Hutchins DA (in press) The effects of changing climate on microzooplankton community structure and grazing: drivers, predictions and knowledge gaps. J Plankton Res

Cembella AD (1998) Ecophysiology and metabolism of paralytic shellfish toxins in marine microalgae. In: Anderson DM, Cembella AD, Hallegraeff GM (eds) Physiological ecology of harmful blooms. NATO ASI Series, Vol G41. Springer-Verlag, Berlin, p 381-403

Cembella AD, Destombe C (1996) Genetic differentiation among Alexandrium populations from eastern Canada. In: Yasumoto T, Oshima Y, Fukuyo Y (eds) Harmful and toxic algal blooms. Intergovernmental Oceanographic Commission of UNESCO, Paris, p 447-450

Cembella AD, Therriault JC (1989) Population dynamics and toxin composition of Protogonyaulax tamarensis from the St. Lawrence estuary. In: Okaichi T, Anderson DM, Nemoto T (eds) Red tides: biology, environmental science and toxicology. Elsevier, New York, NY, p 81-84

Cembella AD, Sullivan JS, Boyer GL, Taylor FJR, Andersen $\mathrm{R}$ (1987) Variation in paralytic shellfish toxin composition within the Protogonyaulux tamarensis/catenella species complex; red tide dinoflagellates. Biochem Syst Ecol 15: 171-186

Cembella AD, Therriault J, Beland P (1988) Toxicity of cultured isolates and natural populations of Protogonyaulax tamarensis from the St. Lawrence estuary. J Shellfish Res 7:611-621

Cermeño P, Dutkiewicz S, Harris RP, Follows M, Schofield O, Falkowski PG (2008) The role of nutricline depth in regulating the ocean carbon cycle. Proc Natl Acad Sci
USA 105:20344-20349

Chateau-Degat ML, Chinain M, Cerf N, Gingras S, Hubert B, Dewailly E (2005) Seawater temperature, Gambierdiscus spp. variability and incidence of ciguatera poisoning in French Polynesia. Harmful Algae 4:1053-1062

Chen S, Gao K (2011) Solar ultraviolet radiation and $\mathrm{CO}_{2}-$ induced ocean acidification interact to influence the photosynthetic performance of the red tide alga Phaeocystis globosa (Prymnesiophyceae). Hydrobiologia 675:105-117

> Cloern JE, Schraga TS, Lopez CB, Knowles N, Grover Labiosa R, Dugdale R (2005) Climate anomalies generate an exceptional dinoflagellate bloom in San Francisco Bay. Geophys Res Lett 32:L14608, doi:10.1029/2005GL 023321

- Coles JF, Jones RC (2000) Effect of temperature on photosynthesis-light response and growth of four phytoplankton species isolated from a tidal freshwater river. J Phycol 36:7-16

Collins S, de Meaux J (2009) Adaptation to different rates of environmental change in Chlamydomonas. Evolution 63: 2952-2965

- Colman B, Huertas IE, Bhatti S, Dason JS (2002) The diversity of inorganic carbon acquisition mechanisms in eukaryotic microalgae. Funct Plant Biol 29:261-270

> Dason JS, Huertas IE, Colman B (2004) Source of inorganic carbon for photosynthesis in two marine dinoflagellates. J Phycol 40:285-292

> Davis TW, Berry DL, Boyer GL, Gobler CJ (2009) The effects of temperature and nutrients on the growth and dynamics of toxic and non-toxic strains of Microcystis during cyanobacteria blooms. Harmful Algae 8:715-725

> de Boer MK, Tyl MR, Fu M, Kulk G and others (2009) Haemolytic activity within the species Fibrocapsa japonica (Raphidophyceae). Harmful Algae 8:699-705

de Veau EJ, Burris JE (1989) Glycolate metabolism in low and high $\mathrm{CO}_{2}$-grown Chlorella pyrenoidosa and Paviova lutheri as determined by ${ }^{18} \mathrm{O}$-labeling. Plant Physiol 91: 1085-1093

Doney SC, Fabry VJ, Feely RA, Kleypas JA (2009) Ocean acidification: the other $\mathrm{CO}_{2}$ problem. Annu Rev Mar Sci 1:169-192

Doucette GJ, King KL, Thessen AE, Dortch Q (2008) The effect of salinity on domoic acid production by the diatom Pseudo-nitzschia multiseries. Nova Hedwigia Beih 133: 31-46

Edwards M, Johns DG, Leterme SC, Svendsen E, Richardson AJ (2006) Regional climate change and harmful algal blooms in the northeast Atlantic. Limnol Oceanogr 51: 820-829

> Eng-Wilmot DL, Hitchcock WS, Martin DF (1977) Effect of temperature on proliferation of Gymnodinium breve and Gomphosphaeria aponina. Mar Biol 41:71-77

> Errera RM, Campbell L (2011) Osmotic stress triggers toxin production by the dinoflagellate Karenia brevis. Proc Natl Acad Sci USA 108:10597-10601

- Etheridge SM, Roesler CS (2005) Effects of temperature, irradiance, and salinity on photosynthesis, growth rates, total toxicity, and toxin composition for Alexandrium fundyense isolates from the Gulf of Maine and Bay of Fundy. Deep-Sea Res II 52:2491-2500

> Feely RA, Sabine CL, Hernandez-Ayon JM, Ianson D, Hales B (2008) Evidence for upwelling of corrosive 'acidified' water onto the continental shelf. Science 320:1490-1492

Fehling J, Davidson K, Bates SS (2005) Growth dynamics of non-toxic Pseudo-nitzschia delicatissima and toxic $P$. 
seriata (Bacillariophyceae) under simulated spring and summer photoperiods. Harmful Algae 4:763-769

> Feng Y, Warner ME, Zhang Y, Sun J, Fu FX, Hutchins DA (2008) Interactive effects of increased $\mathrm{pCO}_{2}$, temperature and irradiance on the marine coccolithophore Emiliania huxleyi (Prymnesiophyceae). Eur J Phycol 43:87-98

Feng Y, Hare CE, Leblanc K, Rose JM and others (2009) Effects of increased $\mathrm{pCO}_{2}$ and temperature on the North Atlantic spring bloom. I. The phytoplankton community and biogeochemical response. Mar Ecol Prog Ser 388: $13-25$

Feng Y, Hare CE, Rose JM, Handy SM and others (2010) Interactive effects of iron, irradiance and $\mathrm{CO}_{2}$ on Ross Sea phytoplankton. Deep-Sea Res I 57:368-383

Flores-Moya A, Rouco M, García-Sańchez MJ, GarcíaBalboa C, González R, Costas E, López-Rodas V (2012) Effects of adaptation, chance, and history on the evolution of the toxic dinoflagellate Alexandrium minutum under selection of increased temperature and acidification. Ecol Evol 2:1251-1259

Franks PJS, Anderson DM (1992) Alongshore transport of a toxic phytoplankton bloom in a buoyancy current: Alexandrium tamarense in the Gulf of Maine. Mar Biol 112:153-164

Fu FX, Warner ME, Zhang Y, Feng Y, Hutchins DA (2007) Effects of increased temperature and $\mathrm{CO}_{2}$ on photosynthesis, growth and elemental ratios of marine Synechococcus and Prochlorococcus (Cyanobacteria). J Phycol 43:485-496

Fu FX, Zhang Y, Warner ME, Feng Y, Hutchins DA (2008a) A comparison of future increased $\mathrm{CO}_{2}$ and temperature effects on sympatric Heterosigma akashiwo and Prorocentrum minimum. Harmful Algae 7:76-90

Fu FX, Mulholland MR, Garcia N, Beck A and others (2008b) Interactions between changing $\mathrm{pCO}_{2}, \mathrm{~N}_{2}$ fixation, and Fe limitation in the marine unicellular cyanobacterium Crocosphaera. Limnol Oceanogr 53:2472-2484

$>$ Fu FX, Place AR, Garcia NS, Hutchins DA (2010) $\mathrm{CO}_{2}$ and phosphate availability control the toxicity of the harmful bloom dinoflagellate Karlodinium veneficum. Aquat Microb Ecol 59:55-65

Gao K, Helbling EW, Häder DP, Hutchins DA (2012a) Responses of marine primary producers to interactions between ocean acidification, solar radiation, and warming. Mar Ecol Prog Ser 470:167-189

- Gao K, Xu J, Gao G, Li Y and others (2012b) Rising $\mathrm{CO}_{2}$ and increased light exposure synergistically reduce marine primary productivity. Nat Clim Change 2:519-523

Gedaria AI, Luckas B, Reinhardt K, Azanza RV (2007) Growth response and toxin concentration of cultured Pyrodinium bahamense var. compressum to varying salinity and temperature conditions. Toxicon 50:518-529

Gentien P (1998) Bloom dynamics and ecophysiology of the Gymnodinium mikimotoi species complex. In: Anderson DM, Cembella AD, Hallegraeff GM (eds) Physiological ecology of harmful algal blooms. NATO ASI Series, Vol. G41. Springer-Verlag, Berlin, p 155-173

Gentien P, Donaghay P, Yamazaki H, Raine R, Reguera B, Osborne T (2005) Harmful algal blooms in stratified environments. Oceanography 18:172-183

- Ghasemzadeh A, Jaafar HZE (2011) Effect of $\mathrm{CO}_{2}$ enrichment on synthesis of some primary and secondary metabolites in ginger (Zingiber officinale Roscoe). Int $\mathrm{J}$ Mol Sci 12:1101-1114

Glibert PM, Burkholder JM (2011) Harmful algal blooms and eutrophication: strategies for nutrient uptake and growth outside the Redfield comfort zone. Chin J Oceanogr 29:724-738

> Glibert P, Seitzinger S, Heil CA, Burkholder JM, Parrow MW, Codispoti LA, Kelly V (2005) The role of eutrophication in the coastal proliferation of harmful algal blooms: new perspectives and new approaches. Oceanography 18:198-209

> Glibert PM, Burkholder JM, Kana TM, Alexander J, Skelton H, Shilling C (2009) Grazing by Karenia brevis on Synechococcus enhances its growth rate and may help to sustain blooms. Aquat Microb Ecol 55:17-30

Gobler CJ, Sunda WG (2012) Ecosystem disruptive algal blooms of the brown tide species, Aureococcus anophagefferens and Aureoumbra lagunensis. Harmful Algae 14: $36-45$

Gobler CJ, Lonsdale DJ, Boyer GL (2005) A synthesis and review of causes and impact of harmful brown tide blooms caused by the alga, Aureococcus anophagefferens. Estuaries 28:726-749

Gobler CJ, Berry DL, Dhyrman SD, Wilhelm SW and others (2011) Niche of harmful alga Aureococcus anophagefferens revealed through ecogenomics. Proc Natl Acad Sci USA 108:4352-4357

Goffart A, Hecq JH, Legendre L (2002) Changes in the development of the winter-spring phytoplankton bloom in the Bay of Calvi (NW Mediterranean) over the last two decades: a response to changing climate? Mar Ecol Prog Ser 236:45-60

Granéli E, Flynn K (2006) Chemical and physical factors influencing toxin content. In: Granéli E, Turner JT (eds) Ecology of harmful algae. Ecological studies, Vol 189. Springer-Verlag, Berlin, p 229-242

Granéli E, Vidyarathna NK, Funari E, Cumaranatunga PRT, Scenati R (2011) Can increases in temperature stimulate blooms of the toxic benthic dinoflagellate Ostreopsis ovata? Harmful Algae 10:165-172

> Grzebyk D, Berland B (1996) Influences of abiotic factors on Prorocentrum minimum (Dinophyceae). J Plankton Res 18:1837-1849

- Grzebyk D, Bechemin C, Ward CJ, Verite C, Codd GA, Maestrini SY (2003) Effects of salinity and two coastal waters on the growth and toxin content of the dinoflagellate Alexandrium minutum. J Plankton Res 25:1185-1199

> Guerrini F, Ciminiello P, Dell'Aversano C, Tartaglione L, Fattorusso E, Boni L, Pistocchi R (2007) Influence of temperature, salinity and nutrient limitation on yessotoxin production and release by the dinoflagellate Protoceratium reticulatum in batch-cultures. Harmful Algae 6: 707-717

> Hales S, Weinstein P, Woodward A (1999) Ciguatera (fish poisoning), El Niño, and Pacific sea surface temperatures. Ecosyst Health 5:20-25

Hales B, Takahashi T, Bandstra L (2005) Atmospheric $\mathrm{CO}_{2}$ uptake by a coastal upwelling system. Global Biogeochem Cycles 19:GB1009, doi:10.1029/2004GB002295

Hall S, Reichardt PB, Neve RA, Boyer GL, Wichman CF, Schroes HK (1982) Studies on the origin and nature of toxicity in Alaskan bivalves: toxins from Protogonyaulax of the Northeast Pacific. J Shellfish Res 2:119

> Hallegraeff GM (2010) Ocean climate change, phytoplankton community responses, and harmful algal blooms: a formidable predictive challenge. J Phycol 46:220-235

> Hamasaki K, Horie M, Tokimitsu S (2001) Variability in toxicity of the dinoflagellate Alexandrium tamarense iso- 
lated from Hiroshima Bay, western Japan, as a reflection of changing environmental conditions. J Plankton Res 23:271-278

- Handy SM, Coyne KJ, Portune KJ, Demir E and others (2005) Evaluating vertical migration behavior of harmful raphidophytes in the Delaware Inland Bays utilizing quantitative real-time PCR. Aquat Microb Ecol 40: 121-132

- Hare CE, Leblanc K, DiTullio GR, Kudela RM and others (2007) Consequences of increased temperature and $\mathrm{CO}_{2}$ for phytoplankton community structure in the Bering Sea. Mar Ecol Prog Ser 352:9-16

> Hinder SL, Hays GC, Edwards M, Roberts EC, Walne AW, Gravenor MB (2012) Changes in marine dinoflagellates and diatom abundance under climate change. Nat Clim Change 2:271-275

> Hoegh-Guldberg O, Bruno JF (2010) The impact of climate change on the world's marine ecosystems. Science 328 : 1523-1528

Honjo T (1993) Overview on bloom dynamics and physiological ecology of Heterosigma akashiwo. In: Smayda TJ, Shimizu Y (eds) Toxic phytoplankton blooms in the sea. Elsevier, New York, NY, p 33-41

Hoogstraten A, Peters M, Timmermans KR, de Baar HJW (2012) Combined effects of inorganic carbon and light on Phaeocystis globosa Scherffel (Prymnesiophyceae). Biogeosciences 9:1885-1896

> Horner RA, Garrison DL, Plumley FG (1997) Harmful algal blooms and red tide problems on the U.S. west coast. Limnol Oceanogr 42:1076-1088

> Hutchins DA, Fu FX, Zhang Y, Warner ME and others (2007) $\mathrm{CO}_{2}$ control of Trichodesmium $\mathrm{N}_{2}$ fixation, photosynthesis, growth rates, and elemental ratios: implications for past, present, and future ocean biogeochemistry. Limnol Oceanogr 52:1293-1304

> Hutchins DA, Mulholland MR, Fu FX (2009) Nutrient cycles and marine microbes in a $\mathrm{CO}_{2}$-enriched ocean. Oceanography 22:128-145

Hwang DF, Lu YH (2000) Influence of environmental and nutritional factors on growth, toxicity, and toxin profile of dinoflagellate Alexandrium minutum. Toxicon 38: 1491-1503

> Ibrahim MH, Jaafar HZE (2011) Enhancement of leaf gas exchange and primary metabolites under carbon dioxide enrichment up-regulates the production of secondary metabolites in Labisia pumila seedlings. Molecules 16: 3761-3777

IPCC (2007) Summary for policymakers. In: Solomon S, Qin D, Manning M, Chen Z and others (eds) Climate change 2007: The physical science basis. Contribution of Working Group I to the fourth assessment report of the Intergovernmental Panel on Climate Change. Cambridge University Press, New York, NY. Available at www.ipcc. ch/publications_and_data/ar4/wg1/en/spm.html

Ishimatsu A, Oda T, Yoshida M, Ozaki M (1996) Oxygen radicals are probably involved in the mortality of yellowtail by Chattonella marina. Fish Sci 62:836-837

> Jackson AE, Ayer SW, Laycock MV (1992) The effect of salinity on growth and amino acid composition in the marine diatom Nitzschia pungens. Can J Bot 70:2198-2201

> Jenks A, Gibbs S (2000) Immunolocalization and distribution of form II Rubisco in the pyrenoid and chloroplast stroma of Amphidinium carterae and form I Rubisco in the symbiont derived plastids of Peridinium foliaceum (Dinophyceae). J Phycol 36:127-138
Johansson N, Graneli E, Yasumoto T, Carlsson P, Legrand C (1996) Toxin production by Dinophysis acuminata and $D$. acuta cells grown under nutrient sufficient and deficient conditions. In: Yasumoto T, Oshima Y, Fukuyo Y (eds) Harmful and toxic algal blooms. Intergovernmental Oceanographic Commission of UNESCO, Paris, p 277-280

John EH, Flynn KJ (2000) Growth dynamics and toxicity of Alexandrium fundyense (Dinophyceae): the effect of changing N:P supply ratios on internal toxin and nutrient levels. Eur J Phycol 35:11-23

Kahn S, Arakawa O, Onoue Y (1998) Physiological investigations of a neurotoxin-producing phytoflagellate, Chattonella marina (Raphidophyceae). Aquacult Res 29:9-17

Kamiyama T, Nagai S, Suzuki T, Miyamura K (2010) Effect of temperature on production of okadaic acid, dinophysistoxin-1, and pectenotoxin-2 by Dinophysis acuminata in culture experiments. Aquat Microb Ecol 60: 193-202

> Kempton JW, Lewitus AJ, Deeds JR, Law JM, Place AR (2002) Toxicity of Karlodinium micrum (Dinophyceae) associated with a fish kill in a South Carolina brackish retention pond. Harmful Algae 1:233-241

Kerr JB, McElroy CT (1993) Evidence for large upward trends of ultraviolet-B radiation linked to ozone depletion. Science 262:1032-1034

Kudela RM, Seeyave S, Cochlan WP (2010) The role of nutrients in regulation and promotion of harmful algal blooms in upwelling systems. Prog Oceanogr 85:122-135

Laabir M, Jauzein C, Genovesi B, Masseret E and others (2011) Influence of temperature, salinity and irradiance on the growth and cell yield of the harmful red tide dinoflagellate Alexandrium catenella colonizing Mediterranean waters. J Plankton Res 33:1550-1563

Lamberto JN, Bourdelais A, Jacocks HM, Tomas C, Baden DG (2004) Effects of temperature on production of brevetoxin and brevetoxin-like compounds. In: Steidinger KA, Landsberg JH, Tomas CR, Vargo GA (eds) Harmful algae 2002. Florida Fish and Wildlife Conservation Commission, Florida Institute of Oceanography, Intergovernmental Oceanographic Commission of UNESCO, Paris, p 155-156

> Landsberg JH, Hall S, Johannessen JN, White KD and others (2006) Saxitoxin puffer fish poisoning in the United States, with the first report of Pyrodinium bahamense as the putative toxin source. Environ Health Perspect 114: 1502-1507

> Lekan DK, Tomas CR (2010) The brevetoxin and brevenal composition of three Karenia brevis clones at different salinities and nutrient conditions. Harmful Algae 9:39-47

Levasseur M, Gamache T, St.Pierre I, Michaud S (1995) Does the cost of $\mathrm{NO}_{3}{ }^{-}$reduction affect the production of harmful compounds by Alexandrium excavatum? In: Lassus P, Arzul G, Erard E, Gentien P, Marcaillou C (eds) Harmful marine algal blooms. Lavoisier, Paris, p 463-468

$>$ Lim PT, Ogata T (2005) Salinity effect on growth and toxin production of four tropical Alexandrium species (Dinophyceae). Toxicon 45:699-710

> Lim PT, Leaw CP, Usup G, Kobiyama A, Koike K, Ogata T (2006) Effects of light and temperature on growth, nitrate uptake, and toxin production of two tropical dinoflagellates: Alexandrium tamiyavanichii and Alexandrium minutum (Dinophyceae). J Phycol 42:786-799

> Liu W, Au DWT, Anderson DM, Lam PKS, Wu RSS (2007) Effects of nutrients, salinity, pH and light:dark cycle on the production of reactive oxygen species in the alga 
Chattonella marina. J Exp Mar Biol Ecol 346:76-86

Lomas MW, Glibert PM (1999) Interactions between $\mathrm{NH}_{4}{ }^{+}$ and $\mathrm{NO}_{3}{ }^{-}$uptake and assimilation: comparison of diatoms and dinoflagellates at several growth temperatures. Mar Biol 133:541-551

Lundholm N, Skov J, Pocklington R, Moestrup O (1994) Domoic acid, the toxic amino acid responsible for amnesic shellfish poisoning, now in Pseudo-nitzschia seriata (Bacillariophyceae) in Europe. Phycologia 33: 475-478

Lundholm N, Skov J, Pocklington R, Moestrup O (1997) Studies on the marine planktonic diatom Pseudonitzschia. 2. Autecology of $P$. pseudodelicatissima based on isolates from Danish coastal waters. Phycologia 36: 381-388

Lundholm N, Hansen PJ, Kotaki Y (2004) Effect of pH on growth and domoic acid production by potentially toxic diatoms of the genera Pseudo-nitzschia and Nitzschia. Mar Ecol Prog Ser 273:1-15

$>$ Maas EW, Brooks HJL (2010) Is photosynthesis a requirement for paralytic shellfish toxin production in the dinoflagellate Alexandrium minutum algal-bacterial consortium? J Appl Phycol 22:293-296

- MacIntyre JG, Cullen JJ, Cembella AD (1997) Vertical migration, nutrition and toxicity in the dinoflagellate Alexandrium tamarense. Mar Ecol Prog Ser 148:201-216

MacIntyre HL, Lomas MW, Cornwell J, Suggett DJ, Gobler CJ, Koch EW, Kana TM (2004) Mediation of benthicpelagic coupling by microphytobenthos: an energy- and material-based model for initiation of blooms of Aureococcus anophagefferens. Harmful Algae 3:403-437

MacIntyre HL, Stutes AL, Smith WL, Dorsey CP, Abraham A, Dickey RW (2011) Environmental correlates of community composition and toxicity during a bloom of Pseudo-nitzschia spp. in the northern Gulf of Mexico. J Plankton Res 33:273-295

Magana HA, Villareal TA (2006) The effect of environmental factors on the growth rate of Karenia brevis (Davis) G. Hansen and Moestrup. Harmful Algae 5:192-198

> Maldonado MT, Hughes MP, Rue EL, Wells ML (2002) The effect of $\mathrm{Fe}$ and $\mathrm{Cu}$ on growth and domoic acid production by Pseudo-nitzschia multiseries and Pseudonitzschia australis. Limnol Oceanogr 47:515-526

Maranda L, Anderson DM, Shimizu Y (1985) Comparison of toxicity between populations of Gonyaulax tamarensis of eastern North American waters. Estuar Coast Shelf Sci 21:401-410

Margalef R (1978) Life-forms of phytoplankton as survival alternatives in an unstable environment. Oceanol Acta 1: 493-509

Marshall JA, Munday B, Yoshizawa Y, Hallegraeff GM (2001) Effect of irradiance on superoxide production by Chattonella marina (Raphidophyceae) from South Australia and Japan. In: Hallegraeff GM, Blackburn SI, Bolch CJ, Lewis RD (eds) Harmful algal blooms 2000. UNESCO, Paris, p 316-319

Marshall JA, de Salas M, Oda T, Hallegraeff GM (2005) Superoxide production by marine microalgae. I. Survey of 37 species from 6 classes. Mar Biol 147:533-540

Martinez R, Orive E, Laza-Martiz A, Seoane S (2010) Growth response of six strains of Heterosigma akashiwo to varying temperature, salinity and irradiance conditions. J Plankton Res 32:529-538

Mengelt C, Prézelin BB (2005) UVA enhancement of carbon fixation and resilience to UV inhibition in the genus
Pseudo-nitzschia may provide a competitive advantage in high UV surface waters. Mar Ecol Prog Ser 301:81-93 Mitra A, Flynn KJ (2006) Promotion of harmful algal blooms by zooplankton predatory activity. Biol Lett 2:194-197

- Moore SK, Trainer VL, Mantua NJ, Parker MS, Laws EA, Backer LC, Fleming LE (2008) Impacts of climate variability and future climate change on harmful algal blooms and human health. Environ Health 7(Suppl 2):S4

> Moore SK, Mantua NJ, Hickey BM, Trainer VL (2009) Recent trends in paralytic shellfish toxins in Puget Sound, relationships to climate, and capacity for prediction of toxic events. Harmful Algae 8:463-477

- Moore SK, Mantua NJ, Salathe EP Jr (2011) Past trends and future scenarios for environmental conditions favoring the accumulation of paralytic shellfish toxins in Puget Sound shellfish. Harmful Algae 10:521-529

$>$ Morton SL, Norris DR, Bomber JW (1992) Effect of temperature, salinity and light-intensity on the growth and seasonality of toxic dinoflagellates associated with ciguatera. J Exp Mar Biol Ecol 157:79-90

Morton SL, Bomber JW, Tindall PM (1994) Environmental effects on the production of okadaic acid from Prorocentrum hoffmannianum Faust I. Temperature, light, and salinity. J Exp Mar Biol Ecol 178:67-77

Nassoury N, Fritz L, Morse D (2001) Circadian changes in ribulose-1,5-bisphosphate carboxylase/oxygenase distribution inside individual chloroplasts can account for the rhythm in dinoflagellate carbon fixation. Plant Cell 13: 923-934

Nielsen LT, Hallegraeff GM, Wright SW, Hansen PJ (2012) Effects of experimental seawater acidification on an estuarine plankton community. Aquat Microb Ecol 65:271-285

> Nimer ND, Iglesias-Rodriguez MD, Merrett MJ (1997) Bicarbonate utilization by marine phytoplankton species. J Phycol 33:625-631

- Oda T, Nakamura A, Shikayama M, Kawano I, Ishimatsu A, Muramatsu $\mathrm{T}$ (1997) Generation of reactive oxygen species by raphidophycean phytoplankton. Biosci Biotechnol Biochem 61:1658-1662

Ogata T, Ishimaru T, Kodama M (1987) Effect of water temperature and light intensity on growth rate and toxicity change in Protogonyaulax tamarensis. Mar Biol 95: $217-220$

Ogata T, Kodama M, Ishimaru T (1989) Effect of water temperature and light intensity on growth rate and toxin production of toxic dinoflagellates. In: Okaichi T, Anderson DM, Nemoto $\mathrm{T}$ (eds) Red tides: biology, environmental science, and toxicology. Elsevier, New York, NY, p 423-426

> Ono K, Khan S, Onoue Y (2000) Effects of temperature and light intensity on the growth and toxicity of Heterosigma akashiwo (Raphidophyceae). Aquac Res 31:427-433

$>$ Orr JC, Fabry VJ, Aumont O, Bopp L and others (2005) Anthropogenic ocean acidification over the twenty-first century and its impact on calcifying organisms. Nature 437:681-686

Oshima Y, Sugino K, Itakura H, Hirota M, Yasumoto T (1990) Comparative studies on paralytic shellfish toxin profile of dinoflagellates and bivalves. In: Graneli E, Sundstrom B, Edler L, Anderson DM (eds) Toxic marine phytoplankton. Elsevier, New York, NY, p 391-396

Paerl HW, Huisman J (2008) Blooms like it hot. Science 320: $57-58$

Paerl HW, Scott JT (2010) Throwing fuel on the fire: synergistic effects of excessive nitrogen inputs and global 
climate change on harmful algal blooms. Environ Sci Technol 44:7756-7758

Pan YL, Rao DVS, Mann KH (1996a) Acclimation to low light intensity in photosynthesis and growth of Pseudonitzschia multiseries Hasle, a neurotoxigenic diatom. J Plankton Res 18:1427-1438

Pan YL, Subba Rao DV, Mann KH (1996b) Changes in domoic acid production and cellular chemical composition of the toxigenic diatom Pseudo-nitzschia multiseries under phosphate limitation. J Phycol 32:371-381

Pan YL, Subba Rao DV, Mann KH, Brown RG, Pocklington R (1996c) Effects of silicate limitation on production of domoic acid, a neurotoxin, by the diatom Pseudonitzschia multiseries. I. Batch culture studies. Mar Ecol Prog Ser 131:225-233

Pan Y, Bates SS, Cembella AD (1998) Environmental stress and domoic acid production by Pseudo-nitzschia: a physiological perspective. Nat Toxins 6:127-135

Parkhill JP, Cembella AD (1999) Effects of salinity, light and inorganic nitrogen on growth and toxigenicity of the marine dinoflagellate Alexandrium tamarense from northeastern Canada. J Plankton Res 21:939-955

> Parsons ML, Aligizaki K, Dechraoui Bottein MY, Fraga S, Morton SL, Penna A, Rhodes L (2012) Gambierdiscus and Ostreopsis: reassessment of the state of knowledge of their taxonomy, geography, ecophysiology, and toxicology. Harmful Algae 14:107-129

> Paz B, Riobo P, Ramilo I, Franco JM (2007) Yessotoxins profile in strains of Protoceratium reticulatum from Spain and USA. Toxicon 50:1-17

> Peperzak L (2003) Climate change and harmful algal blooms in the North Sea. Acta Oecol 24(Suppl 1):S139-S144

$>$ Peperzak L (2005) Future increase in harmful algal blooms in the North Sea due to climate change. Water Sci Technol 51:31-36

> Pezzolesi L, Guerrini F, Ciminiello P, Dell'Aversano C and others (2012) Influence of temperature and salinity on Ostreopsis cf. ovata growth and evaluation of toxin content through HR LC-MS and biological assays. Water Res 46:82-92

> Phlips EJ, Badylak S, Bledsoe E, Cichra M (2006) Factors affecting the distribution of Pyrodinium bahamense var. bahamense in coastal waters of Florida. Mar Ecol Prog Ser 322:99-115

> Pistocchi R, Pezzolesi L, Guerrini F, Vanucci S, Dell'Aversano C, Fattorusso E (2011) A review on the effects of environmental conditions on growth and toxin production of Ostreopsis ovata. Toxicon 57:421-428

Polovina JJ, Howell EA, Abecassis M (2008) Ocean's least productive waters are expanding. Geophys Res Lett 35: L03618, doi:10.1029/2007GL031745

Proctor NH, Chan SX, Trevor AJ (1975) Production of saxitoxin by cultures of Gonyaulax catenella. Toxicon 13:1-9

Ramsey UP, Douglas DJ, Walter JA, Wright JL (1998) Biosynthesis of domoic acid by the diatom Pseudonitzschia multiseries. Nat Toxins 6:137-146

Rhodes L (2011) World-wide occurrence of the toxic dinoflagellate genus Ostreopsis Schmidt. Toxicon 57:400-407

Riebesell U (2004) Effects of $\mathrm{CO}_{2}$ enrichment on marine phytoplankton. J Oceanogr 60:719-729

> Riebesell U, Schulz KG, Bellerby RGJ, Botros M and others (2007) Enhanced biological carbon consumption in a high $\mathrm{CO}_{2}$ ocean. Nature 450:545-548

Riebesell U, Bellerby RGJ, Engel A, Fabry VJ and others (2008) Comment on 'Phytoplankton calcification in a high $\mathrm{CO}_{2}$ world.' Science 322:1466

> Roeder K, Erler K, Kibler S, Tester P and others (2010) Characteristic profiles of ciguatera toxins in different strains of Gambierdiscus spp. Toxicon 56:731-738

> Rose JM, Feng Y, Gobler CJ, Gutierrez R, Hare CE, Leblanc $\mathrm{K}$, Hutchins DA (2009) Effects of increased $\mathrm{pCO}_{2}$ and temperature on the North Atlantic spring bloom. II. Microzooplankton abundance and grazing. Mar Ecol Prog Ser 388:27-40

> Rost B, Riebesell U, Burkhardt S, Sültermeyer D (2003) Carbon acquisition of bloom-forming marine phytoplankton. Limnol Oceanogr 48:55-67

Rost B, Richter K, Riebesell U, Hansen PJ (2006) Inorganic carbon acquisition in red tide dinoflagellates. Plant Cell Environ 29:810-822

Rost B, Zondervan I, Wolf-Gladrow D (2008) Sensitivity of phytoplankton to future changes in ocean carbonate chemistry: current knowledge, contradictions and research directions. Mar Ecol Prog Ser 373:227-237

Royal Society (2005) Ocean acidification due to increasing atmospheric carbon dioxide. Policy document 12/05. Science Policy Section, The Royal Society, London. Latimer Trend and Co, Plymouth

Sarmiento JL, Slater R, Monfray P, Barber R and others (2002) Response of the ocean biology to future climate change. OS 2002 meeting. Trans Am Geophys Union (Ocean Sciences Meet Suppl) 83:OS187 (abstract)

Schnetzer A, Miller PE, Schaffner RA, Stauffer BA and others (2007) Blooms of Pseudo-nitzschia and domoic acid in the San Pedro Channel and Los Angeles harbor areas of the Southern California Bight, 2003-2004. Harmful Algae 6:372-387

Scholin CA, Gulland F, Doucette GJ, Benson S and others (2000) Mortality of sea lions along the central California coast linked to a toxic diatom bloom. Nature 403:80-84

Schonhof I, Klaring HP, Krumbein A, Schreiner M (2007) Interaction between atmospheric $\mathrm{CO}_{2}$ and glucosinolates in broccoli. J Chem Ecol 33:105-114

Shanley E, Vargo GA (1993) Cellular composition, growth, photosynthesis, and respiration rates of Gymnodinium breve under varying light levels. In: Smayda TJ, Shimizu $\mathrm{Y}$ (eds) Toxic phytoplankton blooms in the sea. Elsevier, New York, NY, p 831-836

Shears NT, Ross PM (2009) Blooms of benthic dinoflagellates of the genus Ostreopsis; an increasing and ecologically important phenomenon on temperate reefs in New Zealand and worldwide. Harmful Algae 8:916-925

> Sheng J, Malkiel E, Katz J, Adolf JE, Place AR (2010) A dinoflagellate exploits toxins to immobilize prey prior to ingestion. Proc Natl Acad Sci USA 107:2082-2087

Shimizu Y, Watanabe N, Wrensford G (1995) Biosynthesis of brevetoxins and heterotrophic metabolism in Gymnodinium breve. In: Lassus P, Arzul G, Erard E, Gentien P, Marcailloi C (eds) Harmful marine algal blooms. Lavoisier, Paris, p 351-357

> Siu G, Young M, Chan D (1997) Environmental and nutritional factors which regulate population dynamics and toxin production in the dinoflagellate Alexandrium catenella. Hydrobiologia 352:117-140

> Smayda TJ (1997) Harmful algal blooms: their ecophysiology and general relevance to phytoplankton blooms in the sea. Limnol Oceanogr 42:1137-1153

> Smayda TJ (2008) Complexity in the eutrophication-harmful algal bloom relationship, with comment on the importance of grazing. Harmful Algae 8:140-151 
Smetacek V, Cloern JE (2008) On phytoplankton trends. Science 319:1346-1348

Sobrino C, Neale PJ, Lubian LM (2005) Interaction of UV radiation and inorganic carbon supply in the inhibition of photosynthesis: spectral and temporal responses of two marine picoplankters. Photochem Photobiol 81:384-393

Sobrino C, Ward ML, Neale PJ (2008) Acclimation to elevated carbon dioxide and ultraviolet radiation in the diatom Thalassiosira pseudonana: effects on growth, photosynthesis, and spectral sensitivity of photoinhibition. Limnol Oceanogr 53:494-505

Sosik HM, Mitchell GB (1994) Effect of temperature on growth, light absorption, and quantum yield in Dunaliella tertiolecta (Chlorophyceae). J Phycol 30:833-840

> Spencer KG, Togasaki RG (1981) Limitations on the utilization of glycolate by Chlamydomonas reinhardtii. Plant Physiol 68:28-32

Srivastava AK, Alexova R, Jeon YJ, Kohli GS, Neilan BA (2011) Assessment of salinity-induced photorespiratory glycolate metabolism in Anabaena sp. PCC 7120. Microbiology 157:911-917

Stoecker DK (1999) Mixotrophy among dinoflagellates. J Eukaryot Microbiol 46:397-401

Stramski D, Sciandra A, Claustre H (2002) Effects of temperature, nitrogen, and light limitation on the optical properties of the marine diatom Thalassiosira pseudonana. Limnol Oceanogr 47:392-403

Suffrian K, Schulz KG, Gutowska MA, Riebesell U, Bleich M (2011) Cellular pH measurements in Emiliania huxleyi reveal pronounced membrane proton permeability. New Phytol 190:595-608

Sun J, Hutchins DA, Feng Y, Seubert EL, Caron DA, Fu FX (2011) Effects of changing $\mathrm{pCO}_{2}$ and phosphate availability on domoic acid production and physiology of the marine harmful bloom diatom Pseudo-nitzschia multiseries. Limnol Oceanogr 56:829-840

Sunda WG, Graneli E, Gobler CJ (2006) Positive feedback and the development and persistence of ecosystem disruptive algal blooms. J Phycol 42:963-974

Tatters AO, Fu FX, Hutchins DA (2012) $\mathrm{A} \mathrm{CO}_{2}$ and silicate synergism determines the toxicity of the harmful bloom diatom Pseudo-nitzschia fraudulenta. PLoS ONE 7: e32116

Thessen AE, Stoecker DA (2008) Distribution, abundance and domoic acid analysis of the toxic diatom genus Pseudo-nitzschia from the Chesapeake Bay. Estuaries Coasts 31:664-672

Thessen AE, Dortch Q, Parsons ML, Morrison W (2005) Effect of salinity on Pseudo-nitzschia species (Bacillariophyceae) growth and distribution. J Phycol 41:21-29

> Thessen AE, Bowers HA, Stoecker DK (2009) Intra- and interspecies differences in growth and toxicity of Pseudo-nitzschia while using different nitrogen sources. Harmful Algae 8:792-810

Tindall DR, Morton SL (1998) Community dynamics and physiology of epiphytic/benthic dinoflagellates associated with ciguatera. In: Anderson DA, Cembella AD, Hallegraeff GM (eds) Physiological ecology of harmful algal blooms. Springer-Verlag, Berlin, p 293-313

Tong M, Kulis DM, Fux E, Smith JL, Hess P, Zhou Q, Anderson DM (2011) The effects of growth phase and light intensity on toxin production by Dinophysis acuminata from the northeastern United States. Harmful Algae 10: 254-264

Tortell PD (2000) Evolutionary and ecological perspectives on carbon acquisition in phytoplankton. Limnol Oceanogr 45:744-750

Tortell PD, DiTullio GR, Sigman DM, Morel FMM (2002) $\mathrm{CO}_{2}$ effects on taxonomic composition and nutrient utilization in an Equatorial Pacific phytoplankton assemblage. Mar Ecol Prog Ser 236:37-43

> Trainer VL, Adams NG, Bill BD, Stehr CM, Wekell JC (2000) Domoic acid production near California coastal upwelling zones, June 1998. Limnol Oceanogr 45:1818-1833

> Trainer VL, Hickey BM, Homer RA (2002) Biological and physical dynamics of domoic acid production off the Washington coast. Limnol Oceanogr 47:1438-1446

> Trainer VL, Hickey BM, Lessard EJ, Cochlan WP and others (2009) Variability of Pseudo-nitzschia and domoic acid in the Juan de Fuca eddy region and its adjacent shelves. Limnol Oceanogr 54:289-308

> Trimborn S, Lundholm N, Thoms S, Richter KU, Krock B, Kansen PJ, Rost B (2008) Inorganic carbon acquisition in potentially toxic and non-toxic diatoms: the effect of $\mathrm{pH}$-induced changes in seawater carbonate chemistry. Physiol Plant 133:92-105

> Usup G, Kulis D, Anderson DM (1994) Growth and toxin production of the toxic dinoflagellate Pyrodinium bahamense var. compressum in laboratory cultures. Nat Toxins $2: 254-262$

Usup G, Kulis DV, Anderson DM (1995) Toxin production in a Malaysian isolate of the toxic dinoflagellate Pyrodinium bahamense var. compressum. In: Lassus P, Arzul G, Erard E, Gentien P, Marcaillou C (eds) Harmful marine algal blooms. Lavoisier, Paris, p 519-524

Usup G, Ahmada A, Matsuoka K, Lim PT, Leaw CP (2012) Biology, ecology and bloom dynamics of the toxic marine dinoflagellate Pyrodinium bahamense. Harmful Algae 14:301-312

> Vanucci S, Guerrini F, Milandri A, Pistocchi R (2010) Effects of different levels of $\mathrm{N}$ - and P-deficiency on cell yield, okadaic acid, DTX-1, protein and carbohydrate dynamics in the benthic dinoflagellate Prorocentrum lima. Harmful Algae 9:590-599

> Vargo GA (2009) A brief summary of the physiology and ecology of Karenia brevis Davis (G. Hansen and Moestrup comb. nov.) red tides on the West Florida Shelf and of hypotheses posed for their initiation, growth, maintenance, and termination. Harmful Algae 8:573-584

> Waggett RJ, Tester PA, Place AR (2008) Anti-grazing properties of the toxic dinoflagellate Karlodinium veneficum during predator-prey interactions with the copepod Acartia tonsa. Mar Ecol Prog Ser 366:31-42

Waggett RJ, Hardison DR, Tester PA (2012) Toxicity and nutritional inadequacy of Karenia brevis: synergistic mechanisms disrupt top-down grazer control. Mar Ecol Prog Ser 444:15-30

Wang Y, Smith WO Jr, Wang X, Li S (2010) Subtle biological responses to increased $\mathrm{CO}_{2}$ concentrations by Phaeocystis globosa Scherffel, a harmful algal bloom species. Geophys Res Lett 37, L09604, doi:10.1029/2010GL042666

Weatherhead EC, Anderson SB (2006) The search for signs of recovery of the ozone layer. Nature 441:39-45

Wells ML, Trick CG, Cochlan WP, Hughes MP, Trainer VL (2005) Domoic acid: the synergy of iron, copper, and the toxicity of diatoms. Limnol Oceanogr 50:1908-1917

White AW (1978) Salinity effects on growth and toxin content of Gonyaulax excavata, a marine dinoflagellate causing paralytic shellfish poisoning. J Phycol 14: 475-479 
Whyte JNC, Ginther NG, Townsend LG (1995) Formation of domoic acid and fatty acids in Pseudo-nitzschia pungens f. multiseries with scale of cultures. J Appl Phycol 7: 199-205

Wilson WB, Collier A (1955) Preliminary notes on culturing of Gymnodinium breve Davis. Science 121:394-395

> Wu H, Gao K (2009) Ultraviolet radiation stimulated activity of extracellular carbonic anhydrate in the marine diatom Skeletonema costatum. Funct Plant Biol 36:137-143

Yamazaki M, Tachibana K, Satake M (2011) Complete ${ }^{13} \mathrm{C}$ labeling pattern of yessotoxin, a marine ladder-frame

Submitted: February 16, 2011; Accepted: November 24, 2011 polyether. Tetrahedron 67:877-880

Zhang Y, Fu FX, Whereat E, Hutchins DA (2006) Bottom-up controls on a mixed-species HAB assemblage: a comparison of sympatric Chattonella subsalsa and Heterosigma akashiwo (Raphidophyceae) isolates from the Delaware Inland Bays, USA. Harmful Algae 5:310-320

Ziska LH, Panicker S, Wojno HL (2008) Recent and projected increases in atmospheric carbon dioxide and the potential impacts on growth and alkaloid production in wild poppy (Papaver setigerum). Clim Change 91: 395-403

Proofs received from author(s): November 11, 2012 